\title{
Causes of Current Account Fluctuations in West African Monetary Union
}

\author{
Amadou Woury Diallo \\ PhD Student in Economics, University of Dakar, Senegal. \\ Email:amadouwourydiallo@gmail.com
}

\begin{abstract}
This study analyzes the sources of current account fluctuations in the West African Monetary Union (WAEMU) economies over the period from 1980 to 2017. It is part of the inter-temporal approach which considers that the dynamics of the current account of a country is influenced by global shocks and transient or permanent domestic shocks. Thus, we developed a three-variable structural autoregressive vector model. This is the international real interest rate that represents the aggregate shock, the ratio of current account to gross domestic product which is the proxy for transient domestic shocks, and the ratio of net output to gross domestic product to measure impact of permanent shocks to the current account. From the theoretical model, structural shocks are identified by applying the long-term restrictions imposed by the inter-temporal approach in the analysis of current account dynamics. The study leads to three major results: 1) current account fluctuations within WAEMU are explained by transient domestic shocks, 2) net product fluctuations are due to permanent domestic shocks, 3) Global or exogenous shocks have a modest contribution to current account fluctuations, but their effects on net income are still significant, especially in the long run.
\end{abstract}

Keywords: Current account, Inter-temporal approach, SVAR, Global shocks, Transient shocks, Permanent Shocks, WAEMU. JEL Classification: F32; F41.

Citation | Amadou Woury Diallo (2020). Causes of Current Account Fluctuations in West African Monetary Union. Asian Journal of Economics and Empirical Research, 7(1): 46-63. History:

Received: 25 November 2019

Revised: 8 January 2020

Accepted: 12 February 2020

Published: 24 March 2020

Licensed: This work is licensed under a Creative Commons

Attribution 3.0 License $(\mathrm{cc})$ EY

Publisher: Asian Online Journal Publishing Group
Funding: This study received no specific financial support.

Competing Interests: The author declares that there are no conflicts of interests regarding the publication of this paper.

Transparency: The author confirms that the manuscript is an honest, accurate, and transparent account of the study was reported; that no vital features of the study have been omitted; and that any discrepancies from the study as planned have been explained.

Ethical: This study follows all ethical practices during writing.

\section{Contents}

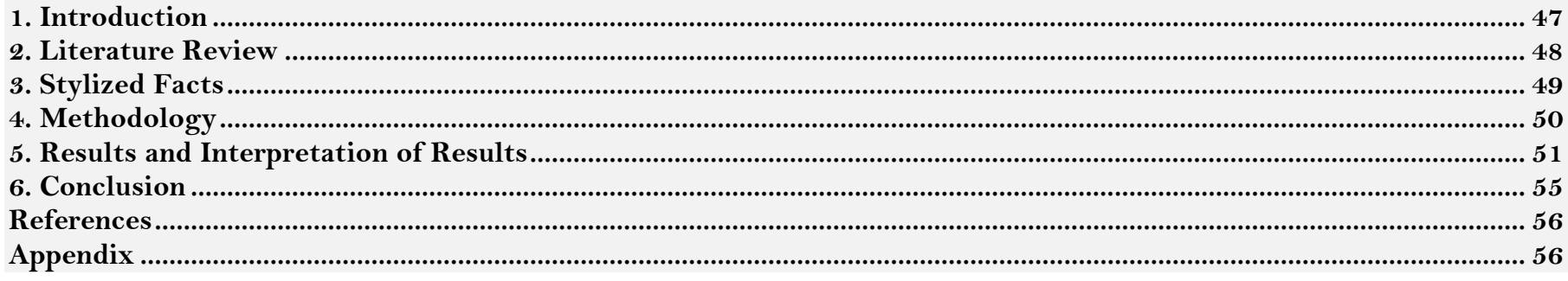




\section{Contribution of this paper to the literature}

This study contributes to existing literature by analyzing the sources of current account fluctuations in the West African Monetary Union (WAEMU) economies over the period from 1980 to 2017.

\section{Introduction}

After its creation in the early 1960s, the West African Monetary Union (WAMU) benefited from a favorable international environment, particularly with high commodity prices, the basis of its economies exports. Thus, the zone has recorded good macroeconomic performance with significant economic growth and controlled inflation. These good macroeconomic performances will lead to the implementation of proactive economic policies to substitute for imports by the States at the industrial level during the decade 1970-1980. Which industrial policies have been financed by external indebtedness (Nubukpo, 2013). But in the early 1980s, the WAEMU economies will have to deal with exogenous shocks, such as falling commodity prices. Thus, difficulties have emerged in terms of public finances with unsustainable debt and budget and current account deficits. These deficits were particularly marked during the 1970-1980 decade, mainly because of the fall in commodity prices on the world market (Plane, 1988). Since then, the current accounts of the member countries of the West African Economic and Monetary Union (WAEMU) are systematically in deficit and the good performances of the zone in terms of economic growth registered in recent years, do not seem to reduce the deficits that keeps growing. In 2017, for example, while economic growth was more than $6 \%$ (West African Economies Central Bank statistics) for the third year in a row, the overall current account deficit of the Union reached $6.8 \%$ of GDP, its highest level since 2008; year of the global economic and financial crisis. Thus, despite the good macroeconomic performance recorded, WAEMU still faces a widening of external deficits which accentuate its financing constraints (Alby, 2018). The worsening of the current account deficits in the Union leads countries to use indebtedness to finance their public investment programs. This is also fueling the burden of the public debt and increasing budget deficits. Fiscal and current imbalances put pressure on international foreign exchange reserves and put the economies at risk of a sharp adjustment. According to the International Monetary Fund (2018) the WAEMU countries incurred a loss of 993 billion CFA Francs on their foreign exchange reserves during the year 2016, thus raised the debate on a necessary devaluation of the common currency. If the scenario of a devaluation of the CFA Franc was then avoided and the deficit was made up, it is thanks to the foreign capital flows resulting in particular from the issues of Eurobonds by the two big States of the zone, Ivory Coast and Senegal. But the exposure of WAEMU countries to the international financial market calls for close monitoring of budget and current account deficits for at least two reasons. First, an accumulation of current account deficits in a context of low resource mobilization capacities exposes countries to a spiral of debt with almost unbearable debt interest charges, as was the case in the late 1980s. Second, economies of the Union would then depend on the conditions of credit on the international market and a hardening of these would strongly affect their external stability. Thus, a decline in growth in developed countries and the tightening of international financial market conditions, which would be linked to the nature of the monetary policies that will be conducted in the United States and in Europe particularly, raise the risk of a sudden stop of foreign capital flows. This would create a serious threat to the stability of the WAEMU economies. Indeed, an accentuation of current deficits, combined with a scarcity of foreign capital, will lead to a deficit in the overall balance of payments and ultimately to a decrease in foreign exchange reserves. In order to avoid a payments crisis, countries could be forced to carry out brutal adjustment policies as it happened with the devaluation of the CFA Franc in 1994. Given such risks to external stability of economies, it is important to look at the causes of current account fluctuations in WAEMU to those deficit drivers and possibly the search for resorption policies.

The objective of this study is to locate the origin of current account fluctuations in WAEMU. Thus, it tries to answer the questions to know: What are the causes of fluctuations of current accounts in WAEMU? Are they external or internal to the economic activity of the countries?

The study is conducted as part of the inter-temporal current account approach developed by Sachs (1981) and Buiter (1981). Following this approach, the current account is used by economic agents to smooth their consumption against income shocks. So its movements come from the factors underlying individual consumption decisions. To find the causes of empirical current account fluctuations, we will use an identification scheme in an autoregressive vector model (VAR) as proposed by Sims (1982) and Blanchard and Quah (1989). This method makes it possible to distinguish specific shocks from global shocks that are supposed to influence the dynamics of the current account in accordance with the inter-temporal approach.

The analysis of impulse response functions (IRF) will be used to identify the nature of shocks that have a significant influence on the dynamics of the current account. In addition, with the decomposition of the variance of the errors, we will be able to check to what extent the exogenous and endogenous shocks contribute in the movements of the current accounts in WAEMU. This will ultimately provide information on empirical sources of current account fluctuations. Such information is crucial for the conduct of States economic policies. Indeed, if external shocks are preponderant then the room for maneuver of national or regional economic policies will be very limited. On the other hand, insofar as current account fluctuations are explained by domestic shocks, policies to reduce or even eliminate deficits would be quite conceivable. Despite the importance of this topic that treats the external stability of West African economies; few studies have been done on this. Our study tries to repair this lag of studies on current account deficits in the case of WAEMU. In this sense, this one contributes to understand the main shocks that drive the current account fluctuations in WAEMU.

The study is organized into four sections. The first section presents a review of the literature on studies of sources of current account fluctuations using the inter-temporal approach. The second section provides a descriptive analysis of the evolution of current accounts of WAEMU countries from 1980 to 2017. The analysis methodology is the subject of the third section that deals with the theoretical model and the specification of the empirical model. Finally, the fourth section deals with the empirical analysis of sources of fluctuations in the current account in WAEMU. The presentation and the analysis of the results make up this last section. 


\section{Literature Review}

This section provides both the theoretical and empirical review of the literature. The inter-temporal current account approach highlights the effects of real factors such as productivity, government spending or international real interest rates on the current account balance. Within the context of analysis, the current account balance results from inter-temporal savings and investment decisions by economic agents. Buiter (1981); Sachs (1981); Obstfeld (1982) and Svensson and Razin (1983) developed the first inter-temporal current account models.

To formally define the current account, the inter-temporal approach starts from the accounting identity that establishes the equality between the national income and the overall expenditure of the country. National income is the sum of domestic production $(\mathrm{Y})$ and factor income paid by the rest of the world equal to interest earned on foreign assets $(\mathrm{rAt})$. While spending includes government spending $\left(\mathrm{G}_{t}\right)$, investment $\left(\mathrm{I}_{t}\right)$ and private consumption $\left(\mathrm{C}_{\mathrm{t}}\right)$ expenditure.

$\mathrm{Y}_{\mathrm{t}}$ is the national production.

$$
Y_{t}+r A_{t}=C_{t}+G_{t}+I_{t}
$$

$\mathrm{C}_{\mathrm{t}}$ the private consumption.

$\mathrm{G}_{\mathrm{t}}$ the public expenses.

$\mathrm{I}_{\mathrm{t}}$ Investment.

$A_{t}$ the net foreign assets and $r$ the constant real interest rate.

The current account balance corresponds to the change in net foreign assets (A), but is also equal to the difference between national income and total expenditure or absorption.

$$
C A_{t}=A_{t+1}-A_{t}=r A_{t}+Y_{t}-C_{t}-G_{t}-I_{t}
$$

As defined in Equation 2, the current account balance depends not only on actual flows of goods but also on international capital flows. The integration of capital movements in the current account dynamics is thus a major innovation of the inter-temporal approach compared to so-called absorption and elasticity approaches of international trade. Indeed, these approaches reduce the balance of current transactions to the trade balance and neglect the movement of capital (Razin, 1993). Hence, the factors that determine the dynamics of the current account are those that also underlie individual savings decisions in the economy.

From Equation 1, changes in the current account balance $(\Delta C A)$ can be written as follows (Razin, 1993):

$$
\Delta C A_{t}=\Delta Y-\Delta I_{t}-\Delta C_{t}+(R-1) C A_{t-1}
$$

Where $\mathrm{R}$ is the market discount factor (see Obstfeld and Rogoff (1994)) :

$$
R_{t, s}=\frac{1}{\prod_{v=t+1}^{S}\left(1+r_{v}\right)}
$$

Equation 3 points up the different shocks that can affect the balance of current transactions. These shocks may be exogenous or domestic and country-specific (Glick \& Rogoff, 1992; Obstfeld \& Rogoff, 1995). The impact of these shocks on the current account differs according to their nature.

After its theoretical statement in the early 1980s, the inter-temporal approach of the current account has been the subject of several empirical studies.

The explicative power of current account dynamics by the inter-temporal model has been tested in several studies (Ghosh, 1995; Otto, 1992). All these pioneering studies used the Present Value Model to check the validity of the conclusions of the inter-temporal current account approach. The results of these studies differ on the power of the inter-temporal model to explain the dynamics of the current account. Subsequent studies, however, have relied on the restrictions imposed by the inter-temporal model to empirically evaluate the sources of current account fluctuations through an autoregressive vector model.

Thus, the role of transitory shocks in the dynamics of the current account has been pointed up by Campa and Gavilan (2006) in the framework of the European Union. The authors tested the validity of the inter-temporal current account model for these economies. Based on quarterly data, the study rejected the model for Finland, Germany and Ireland. On the other hand, it concluded that the model correctly traced the evolution of the current accounts of countries such as Belgium, France, Italy, Netherlands, Portugal and Spain. In addition, the authors have shown that current account fluctuations are determined by the two shocks of relative price changes and expectations of future income, the relative importance of which varies by country. Relative price movements account for the majority of current account fluctuations in Italy and the Netherlands, while future income expectations are responsible for fluctuations in the current accounts of Belgium, Portugal and Spain.

The preponderance of transient productivity shocks over global and permanent shocks was also found by Kano (2003). The author develops a three-variable structural autoregressive vector (SVAR) model to explain current account fluctuations in Canada and the United Kingdom. The study identifies three types of shocks: transient specific shocks, permanent specific shocks and global shocks. The latter are represented by the world real interest rate, while the changes in net output and the ratio of the current account to the net domestic output are the respective proxies of the transitory and permanent specific shocks. The results of the study show that shocks transitory specificities are at the origin of current account movements and therefore explain most of its fluctuations. However, the role of these shocks in the variations of the net domestic product remains very limited.

In addition, Bussiere, Karadimitropoulou, and Leon-Ledesma (2017) underlined that temporary domestic shocks explain for a large proportion, the current account fluctuations in the case of the G-6 economies.

Other studies have found that global shocks predominate in sources of current account fluctuations. Indeed, in contrast, to the theoretical predictions of the inter-temporal approach, Hoffmann (2013) points out that China's current account surpluses are explained by global shocks. Dunne and Makanza (2016) have also found that current account is affected by global monetary shocks in the case of South Africa.

The weak role played by transitory domestic shocks in the current account fluctuations of the G6 economies was also found in the study by Karadimitropoulou and Ledesma (2014). The authors use a structural VAR model with four variables. In addition to changes in net output, current account ratio to gross domestic product and international interest rate, the study takes into account the real exchange rate. Four shocks are highlighted: external supply shocks, domestic and permanent net production shocks, preference shocks and transitory and specific production shocks. The authors reach three major conclusions. The first is that the Present Value Model of 
the current account is accepted for all countries except for France. The second major result of the study is that external and preferential supply shocks determine current account fluctuations. Finally, the last result of this study points out that the current account response to transient domestic shocks is less important than it has been in previous studies.

Pioneering studies of current account dynamics through the inter-temporal approach develop a "Present Value Model" to test the validity of the restrictions induced by the approach. However, the most recent studies on the current account adopting the inter-temporal approach directly integrate the restrictions imposed by a constrained autoregressive vector model.

Studies that incorporated these formal limitations of the approach into a constrained autoregressive vector model attempted to explain the origin of current account and net output fluctuations. We can note that the approach seems more suited to small open economies than to industrialized countries. Indeed, the standard intertemporal current account model fails to explain observed current account with persistent changes in consumption (Shibata, 2018). However, capital movements, the inclusion of which in the study of current account dynamics remains the major innovation of the inter-temporal approach compared to traditional approaches, are less important in developing countries. Both of these limitations could undermine the scope of the approach's contributions in the study of current account dynamics.

\section{Stylized Facts}

In this section, we analyze the evolution of the balance of the current accounts of the countries of the Union such as the balance of payments national account except Guinea Bissau. The withdrawal of Guinea Bissau from the sample is explained by the lack of available data on the variables considered, covering the study period from 1980 to 2017. Current account balances in WAEMU countries are systematically in deficit over the entire period except for a few years when some countries recorded a surplus See Figure 1.

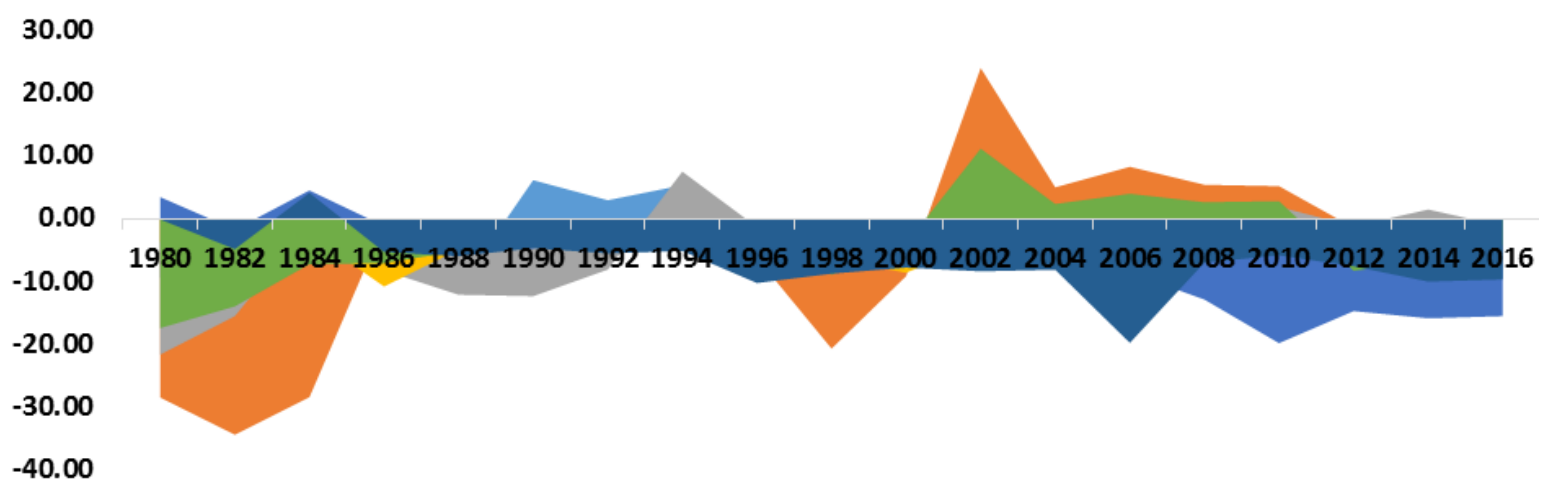

$-40.00$

$$
\because \text { BEN } \square \text { BUR } \square \mathrm{Cl} \square \text { MLI } \quad \text { NIG } \square \text { SEN } \quad \text { TOG }
$$

Figure-1. Evolution of the ratio current account to GDP.

Thus, we can identify three sub-periods in the evolution of WAEMU countries' current account balances. The first sub-period corresponds to the 1980-1990 decade. This is marked by a significant level of current account deficits in WAEMU countries. In fact, starting in 1980, there is a widening of the deficits of the different countries. This is due to soaring prices of energy products following the oil shocks of 1973 and 1979. This has a double deficit effect on the current account. On the one hand, rising energy prices will exacerbate the bill for hydrocarbon imports. There is a deterioration in the trade balance of countries that are all net importers. On the other hand, to comply with their internal growth constraint, countries are required to borrow to finance the current account deficit. As a result, government debt and the interest payments it generates will increase. Since these interests are partly paid by export earnings, the current account deficit of countries is widening.

But this period is also marked by the deterioration of the terms of trade of the primary products which constitute the basis of the exports of the WAEMU economies. This situation seriously undermines the public finances of the countries of the zone until the beginning of the 1990 s and will inevitably lead to the devaluation of the single currency.

The second phase of WAEMU current account developments is between the mid-1990s and the early 2000 . This period corresponds to the $50 \%$ devaluation of the common currency of the eight WAEMU countries, the FCFA, towards the French Franc that was the currency of linking (and the Euro since its entry into force in 1998). It is marked by moderate movements in countries current account balances around the equilibrium. Indeed, after the devaluation, the situation of current payments in the Union, which recorded surpluses in 1994, improved. However, this surplus soon gave way to the return of deficits as early as the following year, even though their level remains less important. This sudden return to deficits after the mechanical surpluses recorded with the devaluation could be explained by "the combined effect of the contraction of foreign trade (-33.3 billion FCFA), of the mechanical increase of the interest charge on the debt foreign exchange (+6 billion FCFA) and the amount of net outflows for unrequited transfers of private origin (+23.5 billion CFA) ". ${ }^{1}$

Finally, the last sub-period starts from 2002, the countries record a clear improvement of their current deficits. However, starting in 2006, deficits started to rise again and reached a new peak in 2008. This new period of large current account deficits coincided with the economic and financial crisis that hit the world towards the end of the decade 2000-2010. Since the WAEMU countries are net importers of most food and energy products, the rise in world prices caused by the crisis increases the import bill and aggravates the trade deficit. This upward trend in current account deficits is still continuing despite the stability or even the decline in certain commodity prices.

${ }^{1}$ Bernard (1995) 
Thus, the analysis of the evolution of the current account can be conducted taking into account that of these two scales. This would make it possible to establish a link between the evolution of the current account in relation to that of the trade balance on the one hand and the savings-investment balance on the other hand. The trade balance is equal to the difference between the value of exports and imports recorded in the balance of payments for each year.

\section{Methodology}

To analyze the sources of current account fluctuations in WAEMU following the inter-temporal approach, we use an autoregressive vector model that directly integrates the long-term restrictions imposed by this approach.

\subsection{The Theoretical Model}

Our model for analyzing sources of current account fluctuations in WAEMU is inspired by the work of Kano (2003). We consider a small open economy with a representative agent whose life is infinite. Let $\left(\mathrm{C}_{t}\right)$ be the consumption of the representative agent at period $t$ and $U\left(C_{t}\right)$ be its utility function at time $t$. This is defined as follows:

$$
U\left(C_{t}\right)=E_{t} \sum_{i=0}^{+\infty} \beta^{i} u\left(C_{t+i}\right)
$$

$\left(E_{t}\right)$ is the operator of the mathematical expectation of information available at time (t). Let $A_{t}, Y_{t}, I_{t}$ and Gt respectively be external assets, production, investment and government expenditures. The representative agent maximizes its utility Equation 4 under the following budget constraint:

$$
A_{t+1}=\left(1+r_{t}\right) A_{t}+Y_{t}-I_{t}-C_{t}
$$

The first order and transversality conditions are given by Equations 6 and 7 :

$$
\begin{array}{cc}
u^{\prime}\left(C_{t}\right)=\beta E_{t}\left[\left(1+r_{t+i}\right) u^{\prime}\left(C_{t+i}\right)\right] \\
\text { With } & \lim _{i \rightarrow \infty} E_{t} R_{t, i} A_{t, i}=0
\end{array}
$$

Condition (7) states that the present value of the country's net foreign assets tends to 0 . In other words, over an infinite time horizon, the economy uses all the resources available to it. Rt is the discount factor of the market at period $t$, for the consumption horizon $t+i$, it is defined as follows in Equation 8:

$$
R_{t, i}= \begin{cases}1 /\left(\pi_{j=t+1}^{t+i}\left(1+r_{j}\right)\right) & \text { if } i \geq 1 \\ 1 & \text { if } i=0\end{cases}
$$

Let's note, $N P_{t}=Y_{t}-I_{t}-G_{t}$, net production. Taking into account the consumer budget constraint Equation 5 and using the condition of transversality Equation 7, we have the ex-ante inter-temporal budgetary constraint of the consumer:

$$
\sum_{i=0}^{\infty} E_{t} R_{t, i} C_{t+i}=\left(1+r_{t}\right) A_{t}+\sum_{i=0}^{\infty} E_{t} R_{t, i} N P_{t, i}
$$

From the Equation 9 of the inter-temporal budget constraint and the transversality condition in Equation 7 , we can define the approximate solution of the ratio of the current account to the net output as follows (See Kano (2003)):

$$
\frac{C A_{t}}{N P_{t}}=b \grave{r}_{t}+[(\sigma-1) c+1] \sum_{i=1}^{\infty} K^{i} E_{t} \grave{r}_{t+i}-\sum_{i=1}^{\infty} K E_{t} \log N P_{t+i}
$$

Equation 10 is the linearized $\log$ version of the current account ratio on net output. It highlights the role of the current account in smoothing the consumption of private agents through its relationship with three factors.

The first factor is the international interest rate. A variation of the latter has an impact on the interest payments on the debt. But the nature of this impact depends on the net external position of the economy in question. If the economy is debtor, which is the case of several developing countries, particularly those of WAEMU, a rise in the world interest rate ( $r$ ) results in an increase in the interest payable to the rest of the world. The consumer anticipates the payment of this additional interest through a new tax. From then on, he will smooth his consumption according to his level of wealth. This changes the ratio of the current account to the net output.

The second factor affecting the ratio of current account to net output is related to inter-temporal substitution and wealth effects. In fact, by varying, the international interest rate forces the representative agent to deviate consumption from its initial trajectory. So, on the one hand, there is an inter-temporal substitution effect between consumption and savings and, on the other hand, a net enrichment effect. As a result, the current account to net production ratio is also changed.

Finally, the third factor expresses the smoothing of consumption by the representative agent following a modification of its expectations on the growth of net output. If in his expectations he foresees a rise in income, the representative agent increases his consumption to the detriment of savings. On the other hand, if he foresees a fall in income, the consumer sets up precautionary savings while giving up certain expenses. The current account balance of the country then depends on the income expectations of the consumer. Thus, in anticipation of an increase in income, the agent consumes more; the current account reacts and becomes deficit. The opposite effect should be observed in the context of expectations of a fall in income by the representative consumer. These three factors explain the role of the current account, which reflects consumer behavior in their savings and investment choices.

\subsection{The Empirical Model}

According to the inter-temporal approach, the current account balance of a small open economy is not influenced by global shocks but rather by domestic shocks. But the impact of these domestic shocks also depends on their persistence. This leads to the modeling of the current account, imposing restrictions on a structural autoregressive vector (Kano, 2003). 
To do this, we develop a three-variable structural autoregressive vector model (SAVM) that is the ratio of current account to GDP (CA_GDP), net output (NP) and the real international interest rate (TIRI). There is the vector of $X_{t}=\left(r_{t}, N P_{t}, \frac{C C_{t}}{P I B_{t}}\right)$.

From these three variables, we identify three types of structural shocks: the global shock through the global real interest rate, the permanent specific shock that relates to net output and the transient specific shock represented by the ratio of the current account to GDP. These shocks are specified as follows:

$\varepsilon_{t}=\left(\varepsilon_{g t}, \varepsilon_{\text {spct }}, \varepsilon_{\text {stct }}\right)$

So we can specify the VAR model in its reduced form:

$$
B X_{t}=\Gamma_{0}+\Gamma_{1}(L) X_{t-1}+\varepsilon_{t} \quad(11)
$$

In Equation 11 above, $B$ is a triangular matrix whose diagonal elements are all equal to unity, $\Gamma(\mathrm{L})$ is the delay operator, $\mathrm{X}_{\mathrm{t}}$ is the variable vector and $\varepsilon_{\mathrm{t}}$ is the vector of structural shocks. We can therefore express the SVAR model in its matrix form:

$\left[\begin{array}{c}r_{t} \\ N P_{t} \\ C A_{t} \\ G D P_{t}\end{array}\right]=\left[\begin{array}{ccc}\Gamma_{r g}(L) & \Gamma_{r c p}(L) & \Gamma_{r c s}(L) \\ \Gamma_{N P g}(L) & \Gamma_{N P c p}(L) & \Gamma_{N P c s}(L) \\ \Gamma_{\text {cagdpg }}(L) & \Gamma_{\text {cagdp }}(L) & \Gamma_{\text {cagdpcs }}(L)\end{array}\right]\left[\begin{array}{c}\varepsilon_{g t} \\ \varepsilon_{s p c t} \\ \varepsilon_{s t c t}\end{array}\right]$

Since the model has three variables $(\mathrm{k}=3)$, we must impose at least three constraints $\left(=\frac{k^{2}-k}{2}\right)$ so that identify it.

The pattern of model identification is based on the orthogonality of the international interest rate to domestic shocks on the one hand and the absence of a long-term response from net output to domestic shocks on the other. The orthogonality of the international interest rate stems from the assumption of a small open economy that faces an interest rate set in the international financial market and on which domestic shocks have no impact.

By imposing the constraints mentioned above, we have:

- The small open economy assumption means that it has no influence on the international real interest rate, so: $\Gamma_{r p c}(1)=\Gamma_{r t c}(1)=0$,

- The transient shock has no effect on long-term net output, resulting in: : $\Gamma_{N P s c}(1)=0$ Finally, by putting $\mathrm{L}=1$, our long-term matrix is written:

$$
\left[\begin{array}{ccc}
\Gamma_{r g}(1) & 0 & 0 \\
\Gamma_{N P g}(1) & \Gamma_{N P c p}(1) & 0 \\
\Gamma_{\text {cagdpg }}(1) & \Gamma_{\text {cagdppc }}(1) & \Gamma_{\text {cagdpsc }}(1)
\end{array}\right]
$$

From this empirical specification, we can now analyze the sources of current account fluctuations in WAEMU.

\section{Results and Interpretation of Results}

In this part, we proceed to the estimation of the structural VAR model and the analysis of the results. But before doing so, we present the data used for the empirical analysis and perform the unit root tests to verify the stationarity of the variables.

\subsection{Data and Stationarity Tests}

The estimation of the empirical model must be preceded by the study of the stationarity of the variables. Indeed, the use of VAR modeling assumes that the series are not cointegrated, but integrated into a first difference. Otherwise, an Error Correction Vector would have been more appropriate.

Thus, the representation of time series Figure 2 in the Appendix shows the presence of a trend and a certain volatility for most of them. This suggests that they are not stationary at level. To be sure, we performed the formal tests of stationarity and cointegration Table 8 in the appendix.

The results of the Johannsen cointegration test conducted on the time series show that they are not cointegrated to a level. On the other hand, the unit root tests lead to the conclusion that all the series are stationary in first difference, so are integrated of order one (I (1)). As a result, our variables lend themselves to autoregressive vector modeling. Therefore, we can proceed to estimate the structural VAR.

In addition, the data used in this study were all converted into quarterly frequency from annual values. For this purpose, methods such as the Proportionality of Denton (1971) allow the conversion of annual data into quarterly frequency. This method consists in generating from the calculated annual ratios, quarterly ratios whose average must be equal to the annual ratio for each year. The implementation was done by concatenation on the $\mathrm{R}$ software. The data come from the International Financial Statistics of the International Monetary Fund (IMF) for the series used to calculate the real world interest rate and the national accounts of the countries available on the basis of the West African economies central bank, economic and financial data for internal variables. The methodology used to construct the various variables is presented in Appendix (Appendix: construction of variables).

From this empirical specification, we can now analyze the sources of current account fluctuations in WAEMU.

\subsection{Analysis of Results}

The interpretation of the structural VAR estimation results is done in two parts. It is the first analysis of the Impulse Response Functions (IRF) presented in Figure 3 in Appendix that will inform us about the positive or negative nature of the response of a given variable to a structural shock. Then we will analyze the decomposition of the residual variances Table 9 in Appendix of the endogenous variables. This analysis makes it possible to measure the contribution of the various structural shocks to the fluctuations of the endogenous variables.

However, a number of standard statistical tests have been applied to the estimated structural VAR models to verify their robustness. These include autocorrelation tests, normality and homokedasticity of estimation errors.

The results of these tests confirm the consistency of the different models. Thus, the residuals of estimation errors are not autocorrelated, they are normally distributed and homokedastic. Therefore, the results can be the 
subject of economic analysis and interpretation. The model estimation is done in two steps. The first one is the estimation of the simple VAR model. The simple VAR model estimated, we proceed the selection of the appropriate lag that will be the same for the SVAR. For this, we begun with 8 lags for all countries. Based on different criteria (AIC, FPE, HQ and SC), we selected the appropriate lag. Then, for all countries, the criteria confirm 8 lags. That is consistent with the length of the data that is not so long. The second step is the estimation of the structural VAR. The results of SVAR estimation on Eviews 9, are in Tables 1 to 7 for each country.

\begin{tabular}{|c|c|c|c|c|}
\hline \multicolumn{5}{|c|}{ Structural VAR Estimates } \\
\hline \multicolumn{5}{|c|}{ Model: $\mathrm{Ae}=\mathrm{Bu}$ where $\mathrm{E}\left[\mathrm{uu}^{\prime}\right]=\mathrm{I}$} \\
\hline \multicolumn{5}{|c|}{ Restriction Type: long-run pattern matrix } \\
\hline \multicolumn{3}{|c|}{ Long-run response pattern: } & & \\
\hline $\mathrm{C}(1)$ & $\mathrm{O}$ & $\mathrm{O}$ & & \\
\hline $\mathrm{C}(2)$ & $\mathrm{C}(4)$ & $\mathrm{O}$ & & \\
\hline \multirow[t]{2}{*}{$\mathrm{C}(3)$} & $\mathrm{C}(5)$ & $\mathrm{C}(6)$ & & \\
\hline & Coefficient & Std. Error & z-Statistic & Prob. \\
\hline $\mathrm{C}(1)$ & 0.599540 & 0.070656 & 8.485281 & 0.0000 \\
\hline $\mathrm{C}(2)$ & -0.002083 & 0.000466 & -4.473220 & 0.0000 \\
\hline $\mathrm{C}(3)$ & 6.160029 & 1.680145 & 3.666367 & 0.0002 \\
\hline $\mathrm{C}(4)$ & 0.002374 & 0.000280 & 8.485281 & 0.0000 \\
\hline $\mathrm{C}(5)$ & -6.932327 & 1.276088 & -5.432484 & 0.0000 \\
\hline $\mathrm{C}(6)$ & 5.881652 & 0.693159 & 8.485281 & 0.0000 \\
\hline Log likelihood & 146.9524 & & & \\
\hline \multicolumn{3}{|c|}{ Estimated A matrix: } & & \\
\hline 1.000000 & 0.000000 & 0.000000 & & \\
\hline 0.000000 & 1.000000 & 0.000000 & & \\
\hline 0.000000 & 0.000000 & 1.000000 & & \\
\hline \multicolumn{3}{|c|}{ Estimated B matrix: } & & \\
\hline 0.261405 & 0.426400 & 0.273126 & & \\
\hline$-9.53 \mathrm{E}-05$ & 0.000220 & $8.17 \mathrm{E}-05$ & & \\
\hline-0.347248 & -0.591264 & 2.062596 & & \\
\hline
\end{tabular}

Table-2. Burkina Faso.

\begin{tabular}{|c|c|c|c|c|}
\hline \multicolumn{3}{|c|}{ Structural VAR Estimates } & & \\
\hline \multicolumn{3}{|c|}{ Model: $\mathrm{Ae}=\mathrm{Bu}$ where $\mathrm{E}\left[\mathrm{uu}^{\prime}\right]=\mathrm{I}$} & & \\
\hline \multicolumn{4}{|c|}{ Restriction Type: long-run pattern matrix } & \\
\hline \multicolumn{3}{|c|}{ Long-run response pattern: } & & \\
\hline $\mathrm{C}(1)$ & $\mathrm{O}$ & $\mathrm{O}$ & & \\
\hline $\mathrm{C}(2)$ & $\mathrm{C}(4)$ & $\mathrm{O}$ & & \\
\hline \multirow[t]{2}{*}{$\mathrm{C}(3)$} & $\mathrm{C}(5)$ & $\mathrm{C}(6)$ & & \\
\hline & Coefficient & Std. Error & z-Statistic & Prob. \\
\hline $\mathrm{C}(1)$ & 0.645069 & 0.076022 & 8.485281 & 0.0000 \\
\hline $\mathrm{C}(2)$ & 0.005128 & 0.000627 & 8.178976 & 0.0000 \\
\hline $\mathrm{C}(3)$ & -29.46430 & 3.639108 & -8.096574 & 0.0000 \\
\hline $\mathrm{C}(4)$ & 0.001002 & 0.000118 & 8.485281 & 0.0000 \\
\hline $\mathrm{C}(5)$ & -5.453202 & 0.878927 & -6.204387 & 0.0000 \\
\hline $\mathrm{C}(6)$ & 3.597462 & 0.423965 & 8.485281 & 0.0000 \\
\hline Log likelihood & 270.6404 & & & \\
\hline \multicolumn{3}{|c|}{ Estimated A matrix: } & & \\
\hline 1.000000 & 0.000000 & 0.000000 & & \\
\hline 0.000000 & 1.000000 & 0.000000 & & \\
\hline 0.000000 & 0.000000 & 1.000000 & & \\
\hline \multicolumn{3}{|c|}{ Estimated B matrix: } & & \\
\hline 0.022019 & 0.050265 & 0.000526 & & \\
\hline$-6.92 \mathrm{E}-05$ & $1.53 \mathrm{E}-05$ & $9.89 \mathrm{E}-06$ & & \\
\hline 0.718459 & -0.186569 & 1.912017 & & \\
\hline
\end{tabular}

Table-3. Ivory Coast.

\begin{tabular}{|c|c|c|c|c|}
\hline \multicolumn{3}{|c|}{ Structural VAR Estimates } & & \\
\hline \multicolumn{3}{|c|}{ Model: $\mathrm{Ae}=\mathrm{Bu}$ where $\mathrm{E}\left[\mathrm{uu}^{\prime}\right]=\mathrm{I}$} & & \\
\hline \multicolumn{4}{|c|}{ Restriction Type: long-run pattern matrix } & \\
\hline \multicolumn{3}{|c|}{ Long-run response pattern: } & & \\
\hline $\mathrm{C}(1)$ & $\mathrm{O}$ & $\mathrm{O}$ & & \\
\hline $\mathrm{C}(2)$ & $\mathrm{C}(4)$ & $\mathrm{O}$ & & \\
\hline \multirow[t]{2}{*}{$\mathrm{C}(3)$} & $\mathrm{C}(5)$ & $\mathrm{C}(6)$ & & \\
\hline & Coefficient & Std. Error & z-Statistic & Prob. \\
\hline $\mathrm{C}(1)$ & 0.592227 & 0.069795 & 8.485281 & 0.0000 \\
\hline $\mathrm{C}(2)$ & 0.002779 & 0.001030 & 2.698684 & 0.0070 \\
\hline $\mathrm{C}(3)$ & -9.829070 & 2.953150 & -3.328334 & 0.0009 \\
\hline $\mathrm{C}(4)$ & 0.005857 & 0.000690 & 8.485281 & 0.0000 \\
\hline $\mathrm{C}(5)$ & -16.16480 & 1.936518 & -8.347354 & 0.0000 \\
\hline $\mathrm{C}(6)$ & 2.086451 & 0.245891 & 8.485281 & 0.0000 \\
\hline Log likelihood & 182.6129 & & & \\
\hline
\end{tabular}




\begin{tabular}{l|c|c|l|l}
\multicolumn{2}{l|}{ Estimated A matrix: } & & & \\
\hline 1.000000 & 0.000000 & 0.000000 & & \\
\hline 0.000000 & 1.000000 & 0.000000 & & \\
\hline 0.000000 & 0.000000 & 1.000000 & & \\
\hline Estimated B matrix: & & & & \\
\hline 0.261607 & 0.042895 & 0.111769 & & \\
\hline$-7.14 \mathrm{E}-05$ & 0.000134 & $6.39 \mathrm{E}-05$ & & \\
\hline 0.159668 & -1.172665 & 1.622546 & & \multicolumn{1}{l}{} \\
\hline
\end{tabular}

Table-4. Mali.

\begin{tabular}{|c|c|c|c|c|}
\hline \multicolumn{3}{|c|}{ Structural VAR Estimates } & & \\
\hline \multicolumn{3}{|c|}{ Model: $\mathrm{Ae}=\mathrm{Bu}$ where $\mathrm{E}\left[\mathrm{uu}^{\prime}\right]=\mathrm{I}$} & & \\
\hline \multicolumn{4}{|c|}{ Restriction Type: long-run pattern matrix } & \\
\hline \multicolumn{3}{|c|}{ Long-run response pattern: } & & \\
\hline $\mathrm{C}(1)$ & $\mathrm{O}$ & 0 & & \\
\hline $\mathrm{C}(2)$ & $\mathrm{C}(4)$ & $\mathrm{O}$ & & \\
\hline \multirow[t]{2}{*}{$\mathrm{C}(3)$} & $\mathrm{C}(5)$ & $\mathrm{C}(6)$ & & \\
\hline & Coefficient & Std. Error & z-Statistic & Prob. \\
\hline $\mathrm{C}(1)$ & 0.233255 & 0.027489 & 8.485281 & 0.0000 \\
\hline $\mathrm{C}(2)$ & -0.002005 & 0.001164 & -1.723294 & 0.0848 \\
\hline $\mathrm{C}(3)$ & -2.988173 & 1.510846 & -1.977815 & 0.0479 \\
\hline $\mathrm{C}(4)$ & 0.006837 & 0.000806 & 8.485281 & 0.0000 \\
\hline $\mathrm{C}(5)$ & -7.870244 & 1.139452 & -6.907045 & 0.0000 \\
\hline $\mathrm{C}(6)$ & 3.971175 & 0.468007 & 8.485281 & 0.0000 \\
\hline Log likelihood & 150.4089 & & & \\
\hline \multicolumn{3}{|c|}{ Estimated A matrix: } & & \\
\hline 1.000000 & 0.000000 & 0.000000 & & \\
\hline 0.000000 & 1.000000 & 0.000000 & & \\
\hline 0.000000 & 0.000000 & 1.000000 & & \\
\hline \multicolumn{3}{|c|}{ Estimated B matrix: } & & \\
\hline 0.102250 & 0.085829 & 0.119475 & & \\
\hline-0.000321 & 0.000461 & $8.85 \mathrm{E}-05$ & & \\
\hline-0.675467 & -1.059857 & 1.805503 & & \\
\hline
\end{tabular}

Table-5. Niger.

\begin{tabular}{|c|c|c|c|c|}
\hline \multicolumn{5}{|c|}{ Structural VAR Estimates } \\
\hline \multicolumn{5}{|c|}{ Model: $\mathrm{Ae}=\mathrm{Bu}$ where $\mathrm{E}\left[\mathrm{uu}^{\prime}\right]=\mathrm{I}$} \\
\hline \multicolumn{5}{|c|}{ Restriction Type: long-run pattern matrix } \\
\hline \multicolumn{3}{|c|}{ Long-run response pattern: } & & \\
\hline $\mathrm{C}(1)$ & 0 & $\mathrm{O}$ & & \\
\hline $\mathrm{C}(2)$ & $\mathrm{C}(4)$ & O & & \\
\hline \multirow[t]{2}{*}{$\mathrm{C}(3)$} & $\mathrm{C}(5)$ & $\mathrm{C}(6)$ & & \\
\hline & Coefficient & Std. Error & z-Statistic & Prob. \\
\hline $\mathrm{C}(1)$ & 0.607951 & 0.071648 & 8.485281 & 0.0000 \\
\hline $\mathrm{C}(2)$ & 0.003046 & 0.000362 & 8.404493 & 0.0000 \\
\hline $\mathrm{C}(3)$ & -34.46490 & 4.179422 & -8.246333 & 0.0000 \\
\hline $\mathrm{C}(4)$ & 0.000299 & $3.53 \mathrm{E}-\mathrm{O} 5$ & 8.485281 & 0.0000 \\
\hline $\mathrm{C}(5)$ & -3.506690 & 0.893949 & -3.922695 & 0.0001 \\
\hline $\mathrm{C}(6)$ & 4.756132 & 0.560516 & 8.485281 & 0.0000 \\
\hline \multicolumn{3}{|c|}{$\begin{array}{l}\text { Log likelihood } \\
283.7102\end{array}$} & & \\
\hline \multicolumn{3}{|c|}{ Estimated A matrix: } & & \\
\hline 1.000000 & 0.000000 & 0.000000 & & \\
\hline 0.000000 & 1.000000 & 0.000000 & & \\
\hline 0.000000 & 0.000000 & 1.000000 & & \\
\hline \multicolumn{3}{|c|}{ Estimated B matrix: } & & \\
\hline 0.005900 & 0.041085 & 0.001756 & & \\
\hline$-5.98 \mathrm{E}-05$ & $3.84 \mathrm{E}-06$ & $1.91 \mathrm{E}-05$ & & \\
\hline 1.448429 & -0.065400 & 1.698540 & & \\
\hline
\end{tabular}

Table-6. Senegal

\begin{tabular}{|c|c|c|c|c|}
\hline \multicolumn{3}{|c|}{ Structural VAR Estimates } & & \\
\hline \multicolumn{3}{|c|}{ Model: $\mathrm{Ae}=\mathrm{Bu}$ where $\mathrm{E}\left[\mathrm{uu}^{\prime}\right]=\mathrm{I}$} & & \\
\hline \multicolumn{4}{|c|}{ Restriction Type: long-run pattern matrix } & \\
\hline \multicolumn{3}{|c|}{ Long-run response pattern: } & & \\
\hline $\mathrm{C}(1)$ & \begin{tabular}{c|c}
$\mathrm{O}$ & \\
\end{tabular} & $\mathrm{O}$ & & \\
\hline $\mathrm{C}(2)$ & $\mathrm{C}(4)$ & $\mathrm{O}$ & & \\
\hline \multirow[t]{2}{*}{$\mathrm{C}(3)$} & $\mathrm{C}(5)$ & $\mathrm{C}(6)$ & & \\
\hline & Coefficient & Std. Error & z-Statistic & Prob. \\
\hline $\mathrm{C}(1)$ & 0.134091 & 0.015803 & 8.485281 & 0.0000 \\
\hline $\mathrm{C}(2)$ & -0.005949 & 0.000982 & -6.058407 & 0.0000 \\
\hline $\mathrm{C}(3)$ & 14.65886 & 2.727122 & 5.375210 & 0.0000 \\
\hline $\mathrm{C}(4)$ & 0.004125 & 0.000486 & 8.485281 & 0.0000 \\
\hline $\mathrm{C}(5)$ & -12.41677 & 1.520325 & -8.167185 & 0.0000 \\
\hline
\end{tabular}




\begin{tabular}{|c|c|c|c|c|}
\hline $\mathrm{C}(6)$ & 2.474230 & 0.291591 & 8.485281 & 0.0000 \\
\hline Log likelihood & 267.7569 & & & \\
\hline \multicolumn{5}{|c|}{ Estimated A matrix: } \\
\hline \begin{tabular}{l|l}
1.000000 & \\
\end{tabular} & 0.000000 & 0.000000 & & \\
\hline 0.000000 & 1.000000 & 0.000000 & & \\
\hline \begin{tabular}{l|l}
0.000000 & \\
\end{tabular} & 0.000000 & 1.000000 & & \\
\hline \multicolumn{5}{|c|}{ Estimated B matrix: } \\
\hline \begin{tabular}{l|l}
0.004875 & \\
\end{tabular} & 0.017399 & 0.004402 & & \\
\hline-0.000208 & 0.000113 & $-1.78 \mathrm{E}-05$ & & \\
\hline-0.180897 & -0.946494 & 1.775149 & & \\
\hline \multicolumn{5}{|c|}{ Table-7. Togo } \\
\hline \multicolumn{5}{|c|}{ Structural VAR Estimates } \\
\hline \multicolumn{5}{|c|}{$\begin{array}{l}\text { Model: } \mathrm{Ae}=\mathrm{Bu} \text { where } \mathrm{E}\left[\mathrm{uu}^{\prime}\right]=\mathrm{I} \\
\end{array}$} \\
\hline \multicolumn{5}{|c|}{ Restriction Type: long-run pattern matrix } \\
\hline \multicolumn{5}{|c|}{\begin{tabular}{l|l} 
Long-run response pattern: & \\
\end{tabular}} \\
\hline $\mathrm{C}(1)$ & \begin{tabular}{c|c}
$\mathrm{O}$ & \\
\end{tabular} & 0 & & \\
\hline $\mathrm{C}(2)$ & $\mathrm{C}(4)$ & $\mathrm{O}$ & & \\
\hline \multirow[t]{2}{*}{$\mathrm{C}(3)$} & $\mathrm{C}(5)$ & $\mathrm{C}(6)$ & & \\
\hline & Coefficient & Std. Error & z-Statistic & Prob. \\
\hline $\mathrm{C}(1)$ & 0.414974 & 0.048905 & 8.485281 & 0.0000 \\
\hline $\mathrm{C}(2)$ & 0.007850 & 0.001048 & 7.493661 & 0.0000 \\
\hline $\mathrm{C}(3)$ & -45.48492 & 5.953699 & -7.639775 & 0.0000 \\
\hline $\mathrm{C}(4)$ & -0.002948 & 0.000347 & -8.485281 & 0.0000 \\
\hline $\mathrm{C}(5)$ & 15.31136 & 1.859042 & 8.236156 & 0.0000 \\
\hline $\mathrm{C}(6)$ & 2.682997 & 0.316194 & 8.485281 & 0.0000 \\
\hline Log likelihood & 244.3602 & & & \\
\hline \multicolumn{5}{|c|}{ Estimated A matrix: } \\
\hline 1.000000 & 0.000000 & 0.000000 & & \\
\hline 0.000000 & 1.000000 & 0.000000 & & \\
\hline 0.000000 & 0.000000 & 1.000000 & & \\
\hline \multicolumn{5}{|c|}{ Estimated B matrix: } \\
\hline 0.044472 & -0.050939 & 0.005758 & & \\
\hline 0.000112 & $7.22 \mathrm{E}-05$ & $9.13 \mathrm{E}-06$ & & \\
\hline-0.201110 & -0.373628 & 1.780004 & & \\
\hline
\end{tabular}

After the SVAR estimation, by applying structural decomposition of Blanchard and Quah (1989) we then obtained the impulse responses of different variables to the structural shocks and we performed a variance decomposition analysis.

\subsubsection{Impulse Responses Analysis}

The analysis of impulse response functions focuses on the current account responses to global, permanent and transient shocks and those of net output to these shocks. Thus, the observation of the shape of the impulse response functions Figure 3 in the Appendix shows for all countries that the current account response to shock on the international interest rate is almost zero. In other words, based on the impulse response functions, we can say that the global shock has almost no impact on the current account of the WAEMU countries. This result is consistent with the theoretical predictions of the inter-temporal approach, which states the absence of a current account response to the global shock in a small open economy. This has also been empirically established by recent studies such as Gross (2001) and especially Kuo (2015) in the context of East Asian economies.

The current account response to the permanent shock remains very low for all WAEMU countries except Senegal. Thus, according to the assumptions of the inter-temporal approach, the permanent shock on net production does not contribute to the fluctuations of the current account of these countries except for Senegal. For the latter we find an important response of the current account to the permanent shock.

With regard to specific transitory shocks, there is an immediate and significant current account response to these shocks for all the countries of the Union. So we can say, based on impulse response functions that current account transactions respond to transitory specific shocks across all economies. In other words, transitory specific shocks are the dominant factor in the current account fluctuations of the WAEMU economies. This result confirms the fundamental assumption of the inter-temporal approach and corresponds to that found by other studies in particular, Gregory and Head (1999) for the G7 economies, Kano (2003) in the framework of Canada and the United Kingdom and Kuo (2015) with regard to East Asian countries.

The analysis of impulse response functions also focuses on the responses of net output to global, specific and permanent shocks. Indeed, one of the strong conclusions of the intertemporal approach is that the shocks that determine the dynamics of the current account are identical to those that affect the changes in net output (Kuo, 2015). Therefore, we also analyze the reactions of net output to different structural shocks.

Thus, the impulse response functions of net output to the global shock of the real interest rate show a very limited impact of this for most countries. This is the case for net production in Benin, Burkina Faso, Mali and Togo, which react only slightly to the global shock. However, there is a negative impact of the global shock on the net production of Ivory Coast, Niger and Senegal. Thus, even if it is not the predominant factor, the global shock has an influence on the net output of all WAEMU countries.

As for permanent domestic shocks, they appear to be the driving force behind fluctuations in net output in WAEMU economies. Indeed, the impulse response functions show a strong reaction of this aggregate to permanent shocks. As a result, the permanent shock appears to be the main source of fluctuations in net output in the WAEMU economies. 
Finally, depending on the scale of responses, transitory domestic shocks appear to have no impact on net output. Indeed, the response of this aggregate to transitory specific shocks is very low or almost nil for all countries.

The analysis of the impulse response functions makes three important remarks. The first is that the global shock would have a very small short-term impact on both the current account and the net output for all WAEMU countries. However, in the long run, it appears to be dominant in the explanation of movements in net output within the economies studied.

The second remark is that the driving forces of the current account and the net production of the countries of the Union are not identical. Indeed, the current account reacts weakly to permanent shocks and very significantly to transient shocks, which are the driving force. While changes in net output are largely explained by permanent shocks, where transient domestic shocks have a negligible impact. The fact that the sources of fluctuations in the current account and net output are not identical is a "puzzle" from the point of view of the inter-temporal approach. In fact, it predicts that the shocks that affect current account movements are those that also determine changes in net output. Kano (2003) produced a similar result for Canada and the United Kingdom.

We must complete this analysis of the impulse response functions (IRF) by that of the decomposition of the variance of the estimates errors which will make it possible to measure the contribution of each type of structural shocks to the fluctuations of the current account and the net output of the Union.

\subsubsection{Analysis of Variance Decomposition}

The decomposition of the variance of current account and net output allows us to measure the contribution of different structural shocks to their fluctuations. In general, as we have pointed out with the analysis of impulse response functions, it appears that permanent and specific domestic shocks are the determinants of the respective changes in net output and current account within the economies of WAEMU.

Thus, for explanations of the variance of the current account to GDP ratio, we note that transient domestic shocks contribute $90 \%$ in the short term and $80 \%$ in the long term with the exception of Mali and Togo. For both countries, the contribution of transitional shocks to current account variance is about $55 \%$ and $70 \%$ in the short term, compared to $30 \%$ for permanent shocks respectively. In the long term, transient shocks explain 50 to $60 \%$ of current account variations in these two countries, compared to $40 \%$ for permanent shocks. Thus, according to the result of the analysis of the impulse response functions, transient domestic shocks are the main cause of current account fluctuations in WAEMU.

As for the variance in net output, it is largely due to permanent domestic shocks. However, global shocks also play an important role in fluctuations in net output, especially in the long run. The contribution of permanent shocks to fluctuations in net output thus runs around $70 \%$ in the short term compared to $30 \%$ due to global shocks and less than $50 \%$ in the long term in the variations in countries' net output. We note that outside countries such as Mali and Niger where the impact of permanent shocks on net output endures in the long run, it is rather the movements in the real world interest rate that account for most of the variance long-term net production.

In sum, the analysis of the variance of the net output and the current account ratio on GDP confirms the remarks resulting from the one made at the level of the impulse response functions. Thus, transient domestic shocks account for the majority of current account fluctuations in the WAEMU economies. While fluctuations in net output originate in domestic permanent shocks, although for a number of countries the real world interest rate plays a major role in the long run.

\section{Conclusion}

The objective of this study is to analyze the main shocks that lead the fluctuations of the current account within the framework of WAEMU whose countries have systematically recorded deficits since the 80s. The study was conducted according to the inter-temporal approach current account. Which approach defines the current account as the difference between domestic savings and investment. This, therefore, bases its analysis of the movements of the current account on the savings and consumption decisions of households in the countries concerned. In addition, the inter-temporal approach allows international capital movements to be accounted for in explaining sources of current account fluctuations, in contrast to traditional macroeconomic models that reduce the current balance to the trade balance.

Thus, the empirical analysis of the sources of current account fluctuations in WAEMU countries was based on an autoregressive vector model. It is a structural vector autoregressive model with three types of shocks whose contribution to current account fluctuations has been underlined by the different previous studies carried out under the inter-temporal approach (Obstfeld \& Rogoff, 1994; Razin, 1993). These shocks are either domestic and permanent, domestic and transient, or exogenous. Transient and permanent domestic shocks are respectively approximated by the ratio of the current account to the gross domestic product and the ratio of net output to gross domestic product. Exogenous shocks are represented by changes in the real international interest rate. The estimation of the model was made on data covering the period 1980-2017 and seven of the eight WAEMU countries.

The empirical results obtained from the analysis of the impulse response functions and the decomposition of the variances make it possible to make the following remarks. In WAEMU, domestic shocks are the main sources of current account and net output fluctuations due to the low participation of countries in international trade and in keeping with their status as small open economies. Thus, transient shocks determine the fluctuations of the current account while the impact of permanent and global shocks on this aggregate is almost weak. This result is consistent with the predictions of the inter-temporal approach, which states that fluctuations in the current account of a small open economy are caused by transient domestic shocks. As for net output, its fluctuations can be explained by permanent domestic shocks in the short term. Nevertheless, in the long run, changes in the real international interest rate are the main cause of fluctuations in net output.

The other conclusion that we can draw from these results is that the shocks that determine the fluctuations of the current account and the net production are not identical under WAEMU. What constitutes a "puzzle" from the 
point of view of the inter-temporal approach. But this same observation was made by Kano (2003) in Canada and the United Kingdom, where current account fluctuations would be explained by transient domestic shocks but which would have a limited influence on changes in net income.

In view of the empirical results, the improvement of the level of current deficits in the WAEMU requires the control of domestic transient shocks. However, this study has some limitations.

First, other sources of current account variations such as supply and preference shocks could have been incorporated and would have improved the model results. However, the availability of data covering the entire study period was lacking.

Secondly, the study only gives an indication of the origin of current account fluctuations, but does not specifically identify the imbalance factors in the specific context of WAEMU. Thus, it would be particularly important to supplement it with another study that would seek to identify precisely the current account deficit factors in WAEMU. If so, it will be interesting to look for current account adjustment policies within the Union based on the deficit factors that would be identified.

\section{References}

Alby, S. (2018). CFA franc: New stress test. Conjoncture 2018, Economic-research.bnpparibas.com., France. 2-10.

Bernard, C. (1995). Devaluation of the FCFA and balance of current payments. Bordeaux IV, France: Center for Development Economics, Montesquieu University

Blanchard, O. J., \& Quah, D. (1989). The dynamic effects of aggregate demand and supply disturbances. The American Economic Reviere, 79(4), 653-673.

Buiter, W. H. (1981). Time preference and international lending and borrowing in an overlapping-generations model. Journal of Political Economy, 89(4), 769-797. Available at: https://doi.org/10.1086/261002.

Bussiere, M., Karadimitropoulou, A., \& Leon-Ledesma, M. A. (2017). Current account dynamics and the real exchange rate: Disentangling the evidence: School of Economics, University of East Anglia, Norwich, UK

Campa, J. M., \& Gavilan, A. (2006). Current accounts in the euro area: An intertemporal approach. Bank of Spain, Working Document No. O638.

Denton, F. T. (1971). Adjustment of monthly or quarterly series to annual totals: An approach based on quadratic minimization. Journal of the American Statistical Association, 66(333), 99-102. Available at: https://doi.org/10.1080/0162 1459.1971.10482227.

Dunne, J. P., \& Makanza, C. S. (2016). Current account dynamics and monetary policy transmission in South Africa. School of Economics Discussion Paper Series, No. 2016-02. School of Economics, University of Cape Town.

Ghosh, A. R. (1995). International capital mobility amongst the major industrialised countries: Too little or too much? The Economic Journal, 105(428), 107-128. Available at: https://doi.org/10.2307/2235322.

Glick, R., \& Rogoff, K. (1992). Global versus country-specific productivity shocks and the current account dynamics. Journal of Monetary Economics, 35, 159-193.

Gregory, A. W., \& Head, A. C. (1999). Common and country specific fluctuations in productivity, investment and the current account. Journal of Monetary Economics, 44(3), 423-45 1. Available at: https://doi.org/10.1016/s0304-3932(99)00035-5.

Gross, D. (2001). Country-specific and global shocks in business cycles. Center for Financial Studies, Germany, Working Paper $\mathrm{N}^{\circ} 2001 / 11$.

Hoffmann, M. (2013). What drives China's current account? Journal of International Money and Finance, 32, 856-883. Available at: ttps://doi.org/10.1016/j.jimonfin.2012.07.005.

International Monetary Fund. (2018). $\mathrm{n}^{\circ} 2018 / 106$

Kano, T. (2003). A structural VAR approach to the intertemporal model of the current account. Bank of Canada, Working Paper $2003-42$.

Karadimitropoulou, A., \& Ledesma, L. M. A. (2014). What are the sources of current accounts fluctuations in the G6 countries? Retrieved from http://www.researchgate.net/publication/26041281.

Kuo, C.-Y. (2015). Is an intertemporal model of the current account valid for East Asian countries? Evidence from structural VAR. Journal of Business Economics and Management, 16(6), 1085-1 108. Available at: https://doi.org/10.3846/16111699.2014.964304.

Nubukpo, K. (2013). Fifty West African monetary union: What have we learned? Financial Economy Review, 2013/2 (No 110), 145-164.

Obstfeld, M. (1982). Aggregate spending and the terms of trade: Is there a Laursen-Metzler effect? NBER Working Paper Series, WP $\mathrm{N}^{\circ} 686$.

Obstfeld, M., \& Rogoff, K. (1994). The intertemporal approach to the current account. NBER Working Paper Series, WP N4893.

Obstfeld, M., \& Rogoff, K. (1995). Exchange rate dynamics redux. NBER Working Paper Series, WP N 4693.

Otto, G. (1992). Testing a present-value model of the current account: Evidence from US and Canadian time series. Journal of International Money and Finance, $11(5), 414-430$. Available at: https://doi.org/10.1016/0261-5606(92)90009-m.

Plane, P. (1988). The factors of imbalances in current payments in the West African Monetary Union (1970-1983). Journal of Political Economy, 98(1), $111-126$

Razin, A. (1993). The dynamic-optimizing approach to the current account: Theory and evidence. NBER Working Paper Series, WP $N^{\circ} 4334$. Sachs, J. (1981). The current account in the macroeconomic adjustment process. Scandinavian Journal of Economics, 84(2), 47-59.

Shibata, A. (2018). Current account dynamics under information rigidity and imperfect capital mobility. ESRI Discussion Papers Series $N^{\circ} 344$. Sims, C. A. (1982). Policy analysis with econometric models. Brookings Papers on Economic Activity, 13(1), 107-164.

Svensson, L. E., \& Razin, A. (1983). The terms of trade and the current account: The Harberger-Laursen-Metzler effect. Journal of Political Economy, 91(1), 97-125. Available at: https://doi.org/10.1086/261130.

\section{Appendix}

\section{Construction of the variables:}

The data used in this study come from the national accounts of the various countries with respect to internal variables and IMF International Financial Statistics (IFS) for the global interest rate. They have been converted to quarterly frequency from annual data.

The international interest rate was constructed using Fisher's formula. In other words, we have calculated the real international interest rate by subtracting the current year's inflation rate from the nominal interest rate of the US treasury in the short term. The calculation of the inflation rate was done by differentiating between the price index of the current year and that of the previous year. Or formally: $\pi_{t}=I P C_{t}-I P C_{t-1}$

$T I R I_{t}=r_{t}-\pi_{t}$. Where $r_{t}$ is the nominal interest rate of the US treasury.

As far as Net output is concerned, it is calculated as the difference between government expenditures, which is equal to the sum of gross fixed capital formation and gross domestic product stock changes.

Finally, the current account to GDP ratio was made by comparing the current account of the balance of payments to the nominal gross domestic product.

The different sets of internal variables thus constructed are divided by the GDP deflator to make them real and then by the total population to conform to the representative agent hypothesis. 
Table-8. Cointegration and unit root tests.

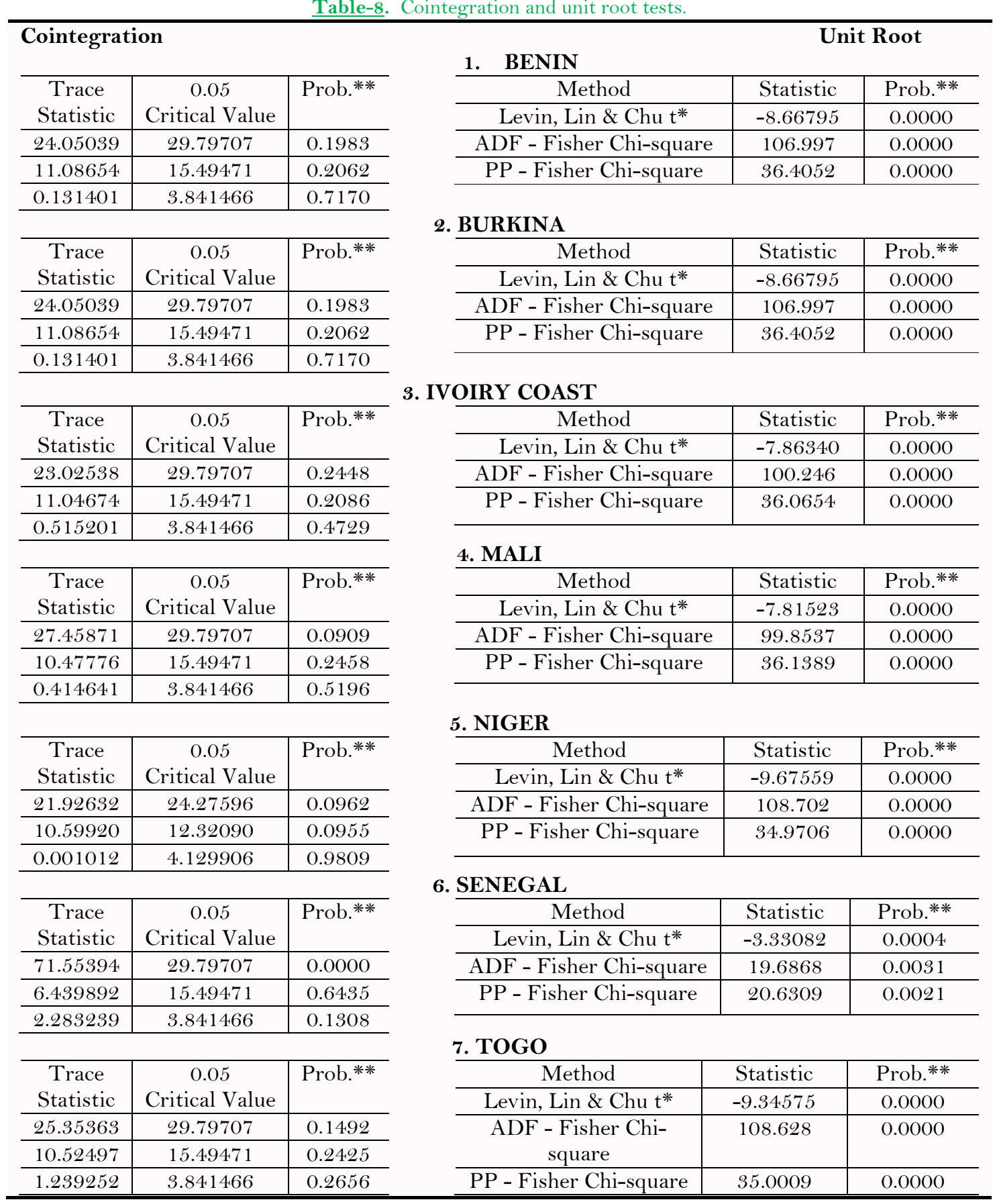

1. Benin
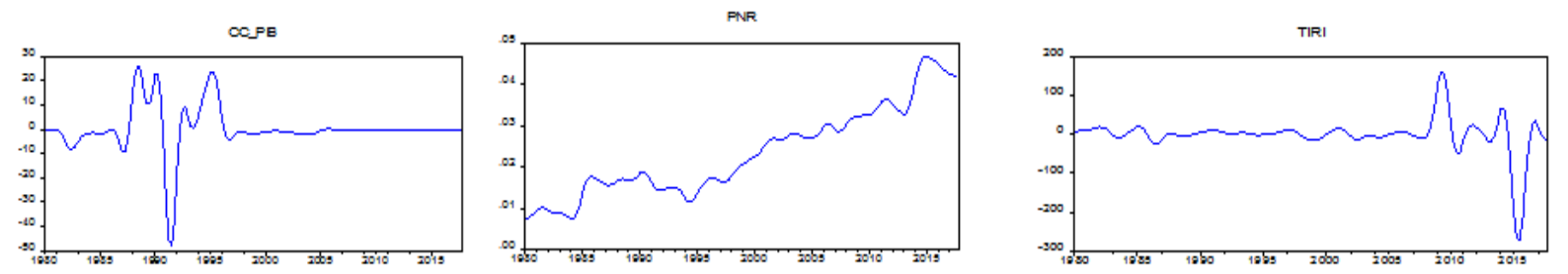

2. Burkina Faso

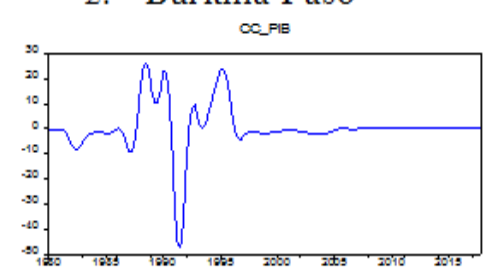

$T \mid R$

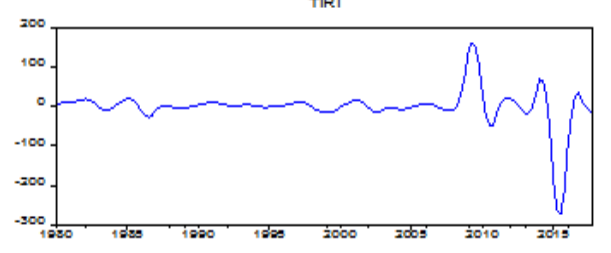




\section{Ivoiry Coast}
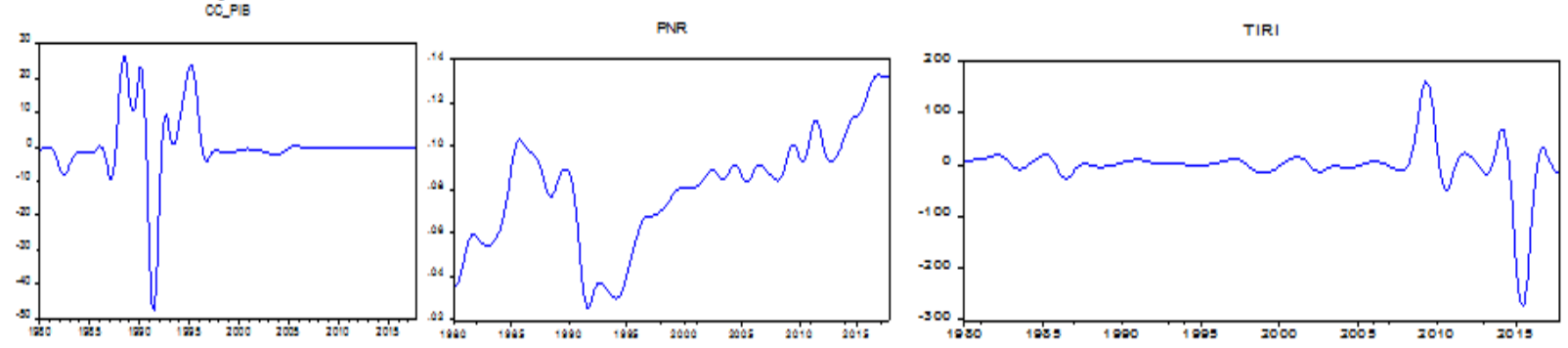

4. Mali
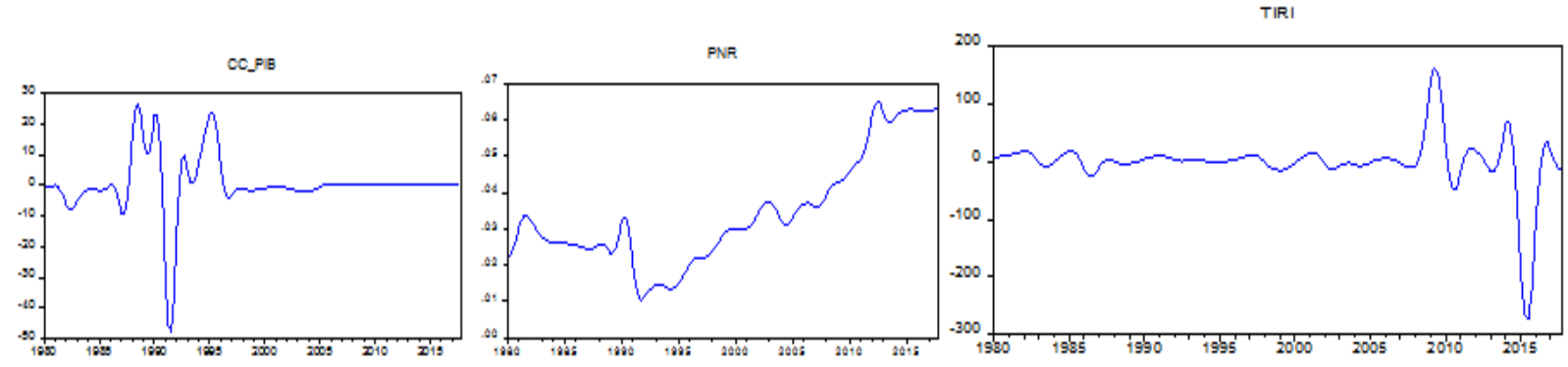

5. Niger
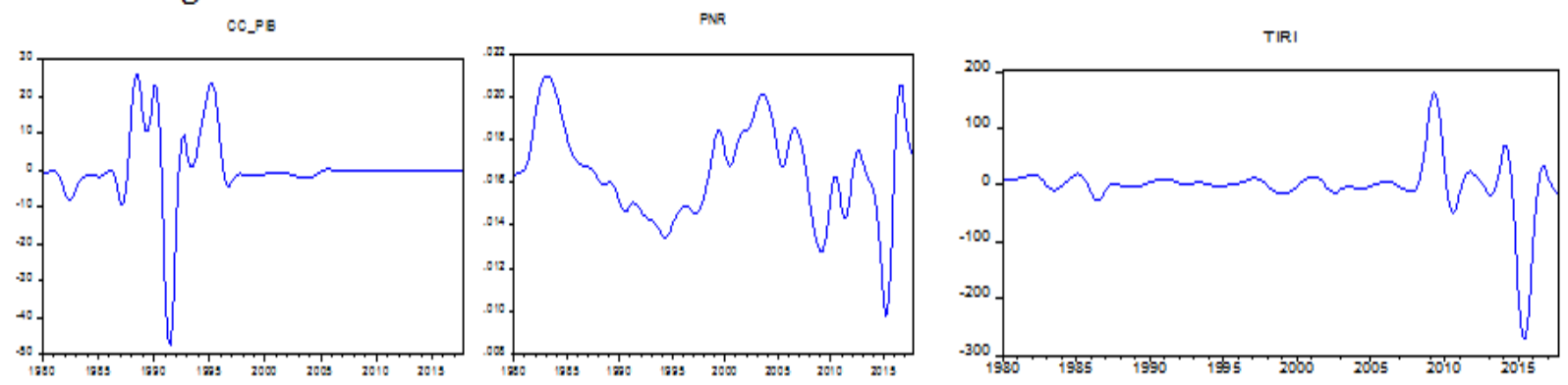

\section{Senegal}
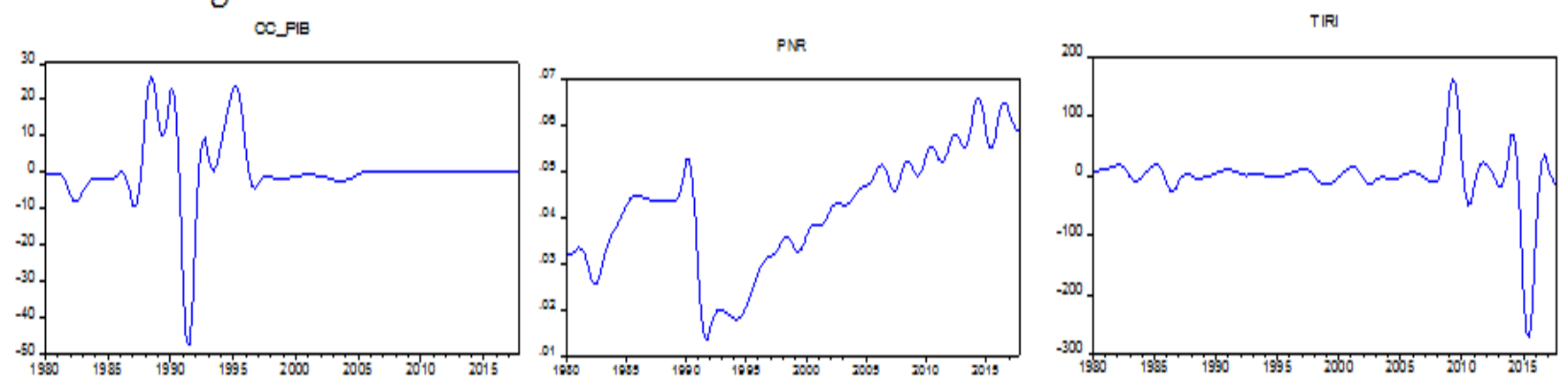

7. Togo
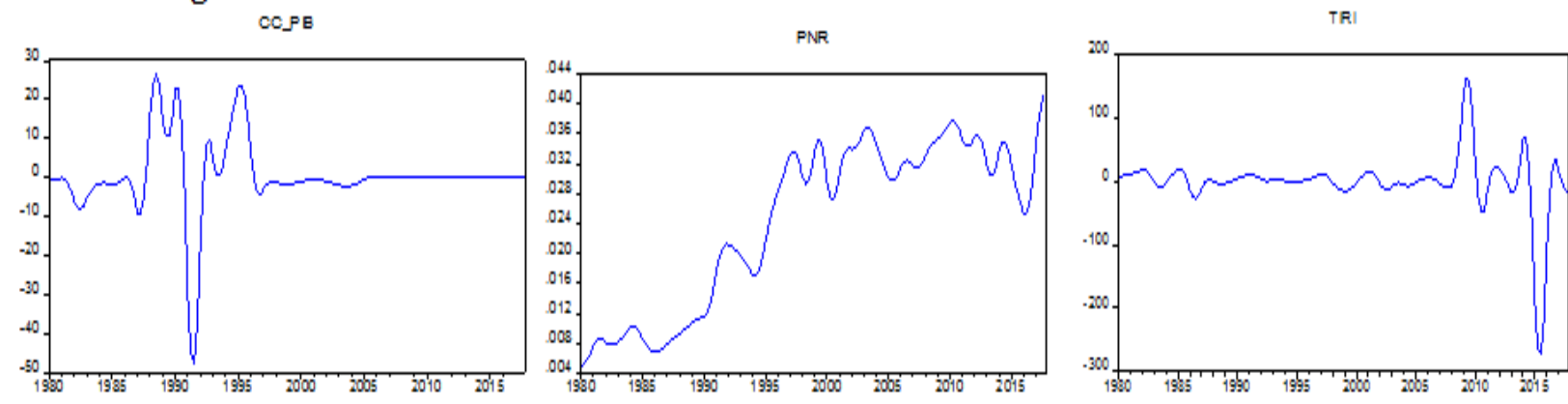

Figure-2. Representation of constructed series. 


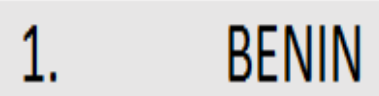

A ooumulared Response ro Nonfaororlzed One S.D. Innovarlons 2 S.E.

A ooumulared Response of PNR ro TIRI

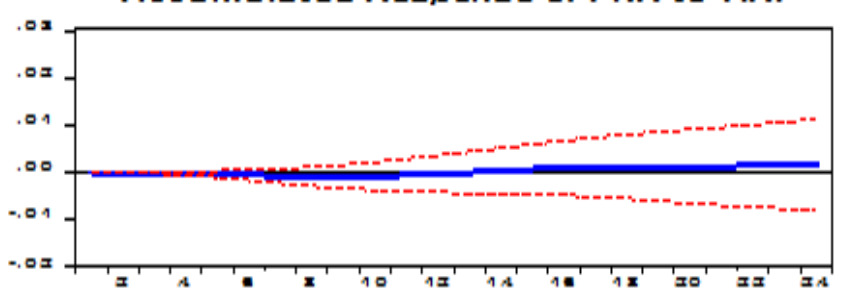

Aooumulared Response of PNR ro CC_PIB

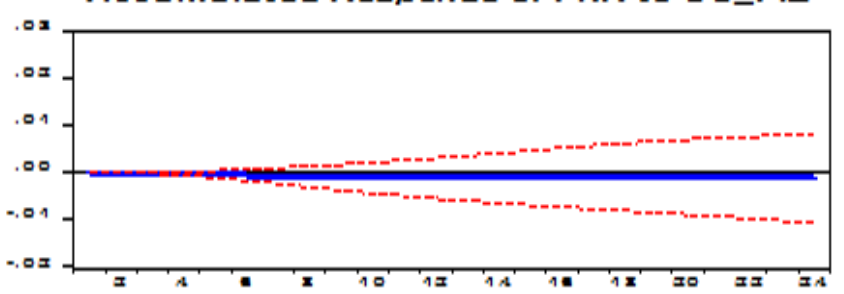

Aooumulared Response of CC_PIB ro PNR

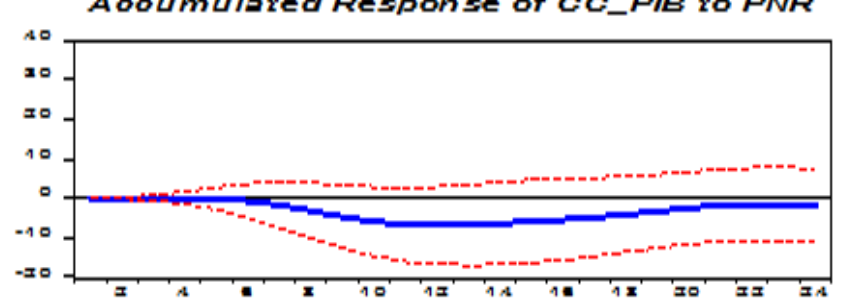

Aooumulared Response of PNR ro PNR

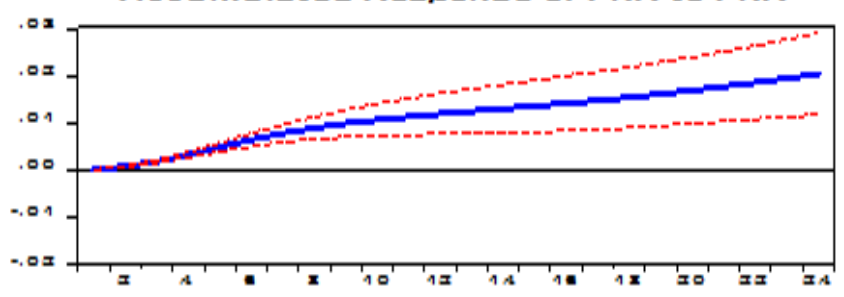

Aooumulared Response of CC_PIB ro TIRI

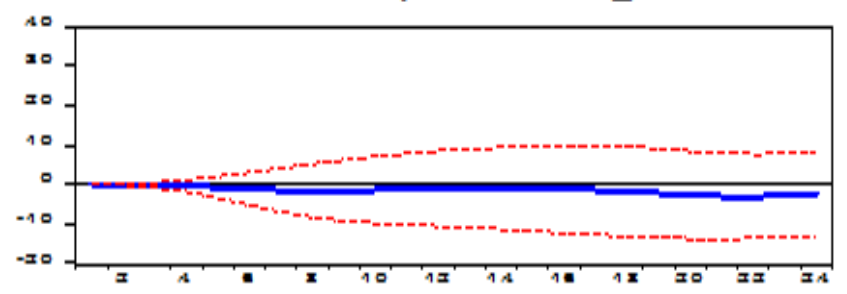

Aooumulared Response of CC_PIB ro CC_PIE

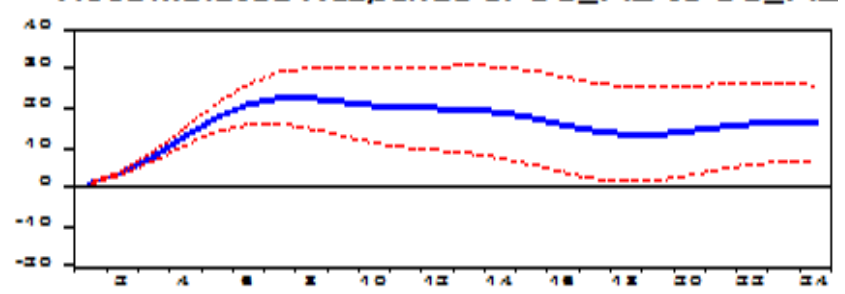

\section{BURKINA FASO}

Accumulated Response to Nonfactorlzed One S.D. Innovatlons \pm 2 S.E.
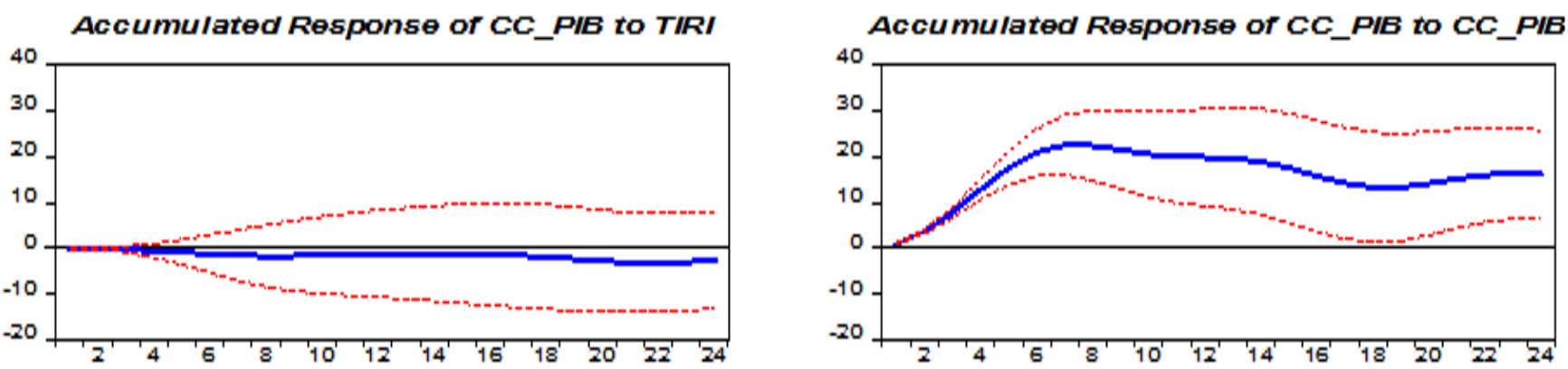

Accumulated Response of CC_PIB to PNR
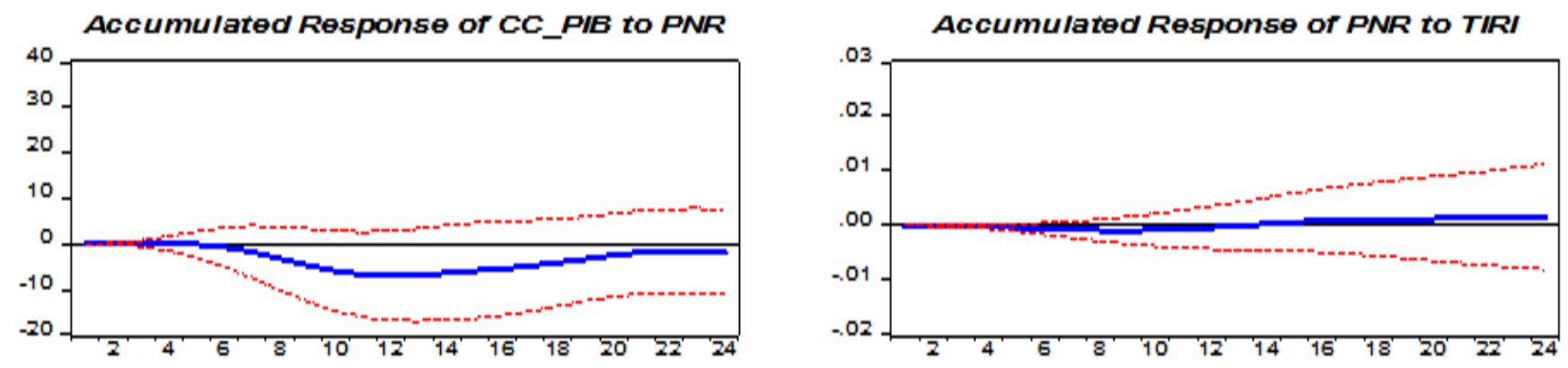

Accumulated Response of PNR to CC_PIB
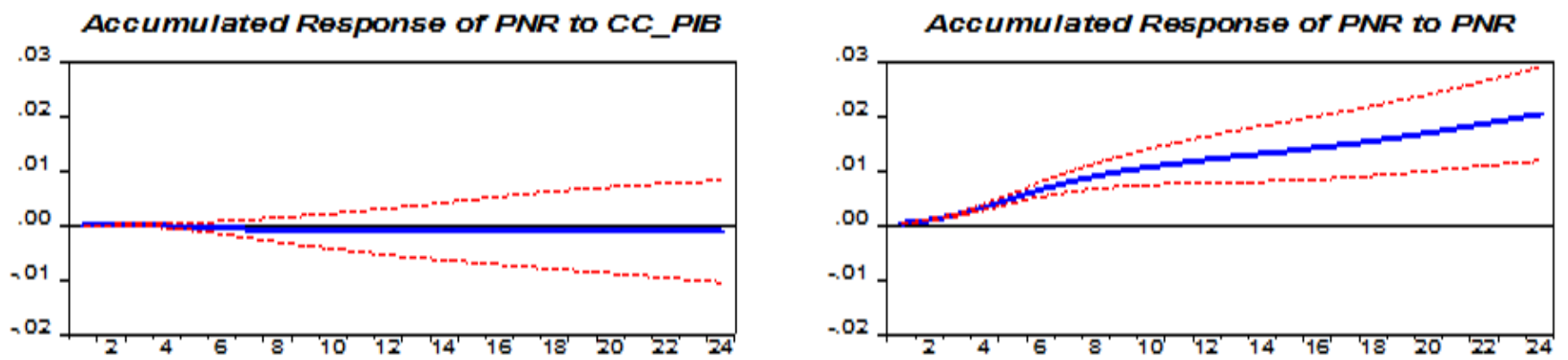


\section{IVOIRY COAST}

Accumulated Response to Nonrac torlzed One S.D. Innovations \pm 2 S.E. Accumulated Response or PNR to TIRI
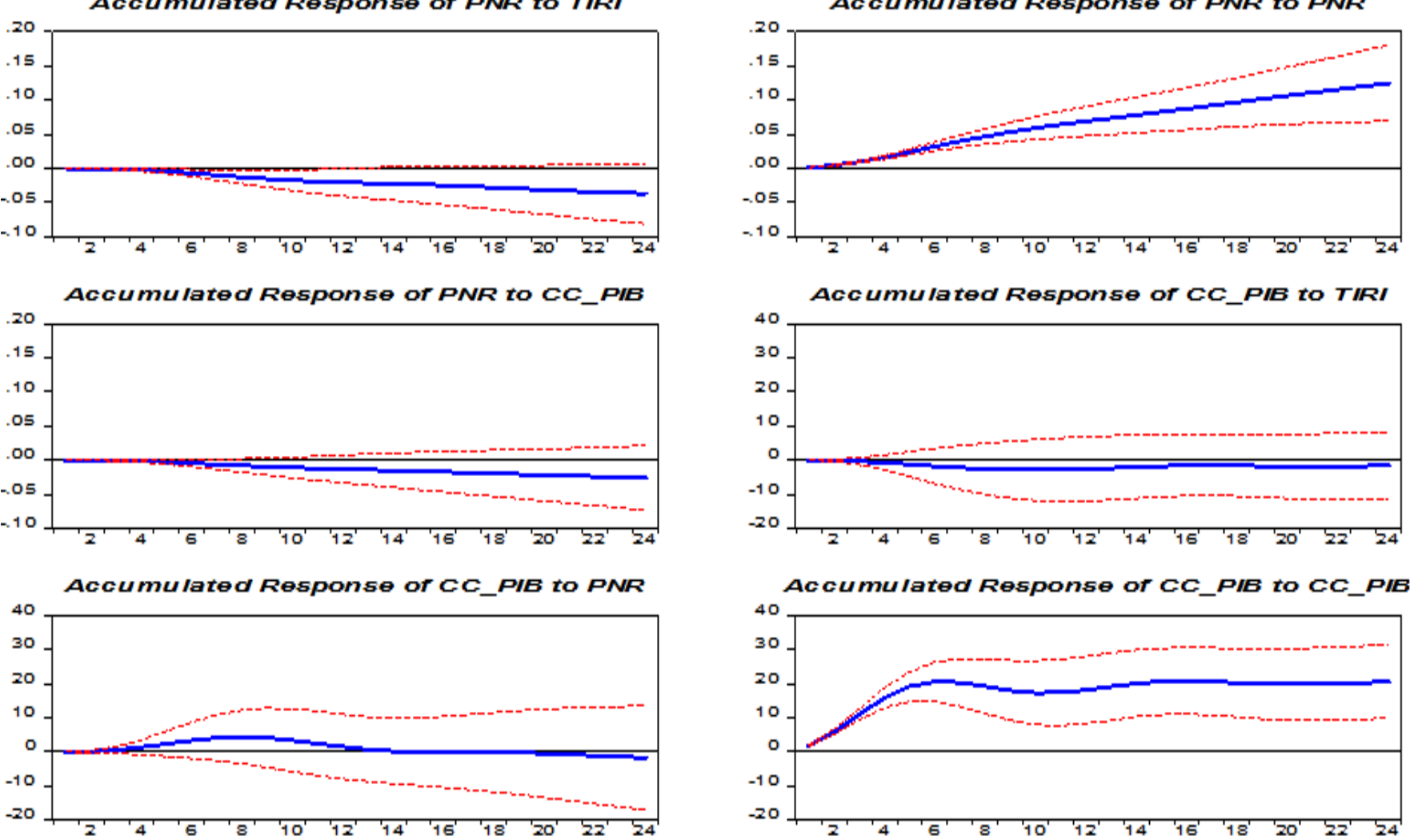

\section{MALI}

Accumulated Response to Nonfactorized One S.D. Innovations \pm 2 S.E. Accumulated Response of PNR to TIRI

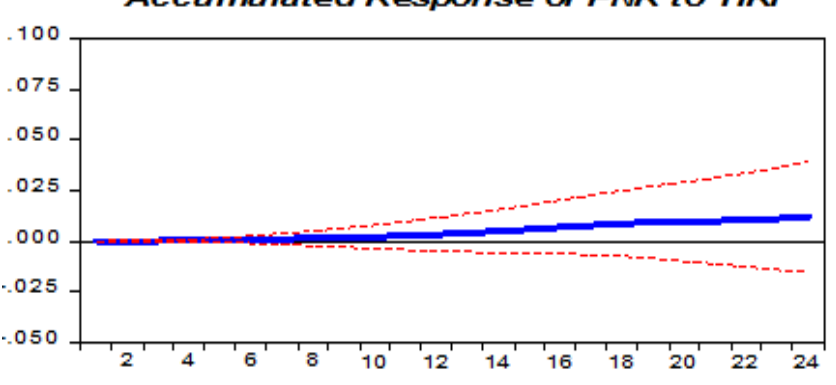

Accumulated Response of PNR to PNR

Accumulated Response of PNR to CC_PIB

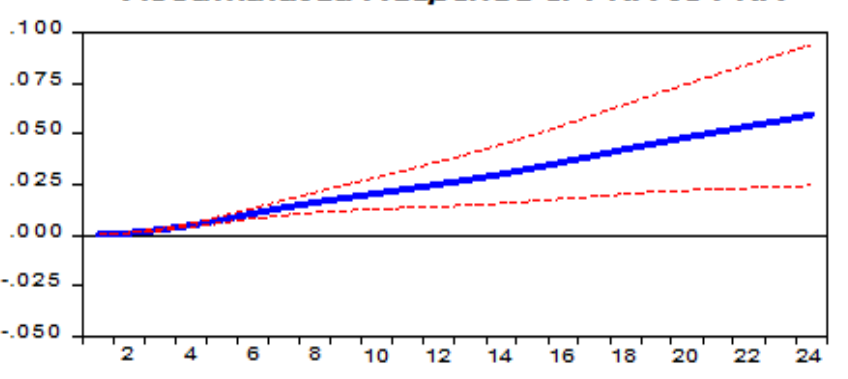

Accumulated Response of CC PIB to TIRI
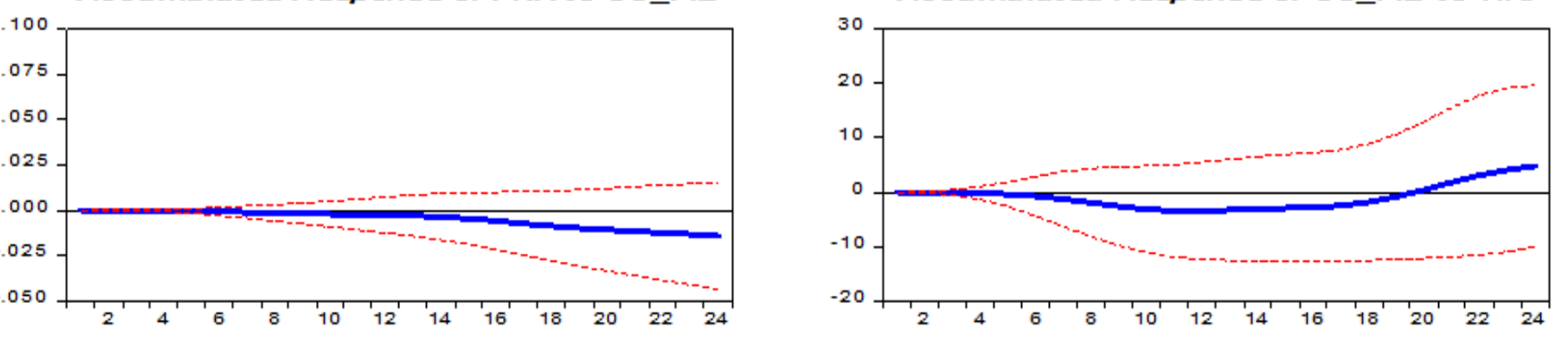

Accumulated Response of CC_PIB to PNR

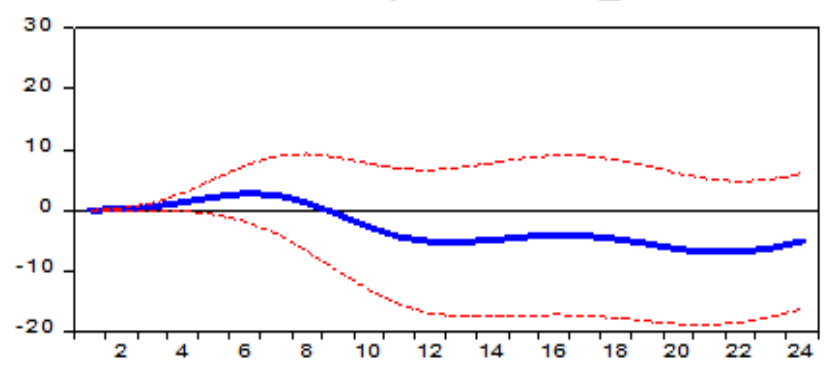

Accumulated Response of CC PIB to CC PIB

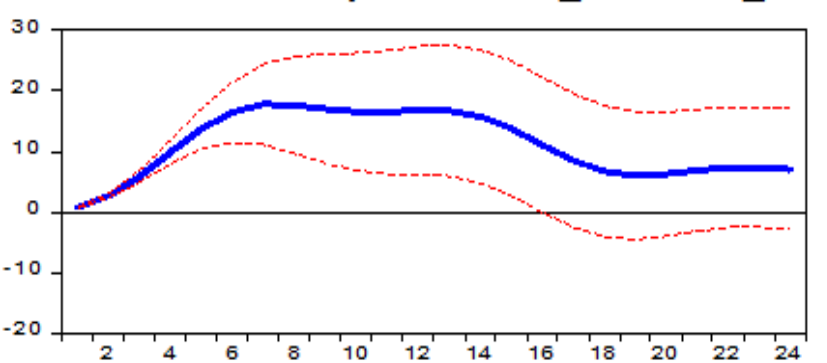




\section{NIGER}

Accumulated Response to Nonfactorized One S.D. Innovations \pm 2 S.E.

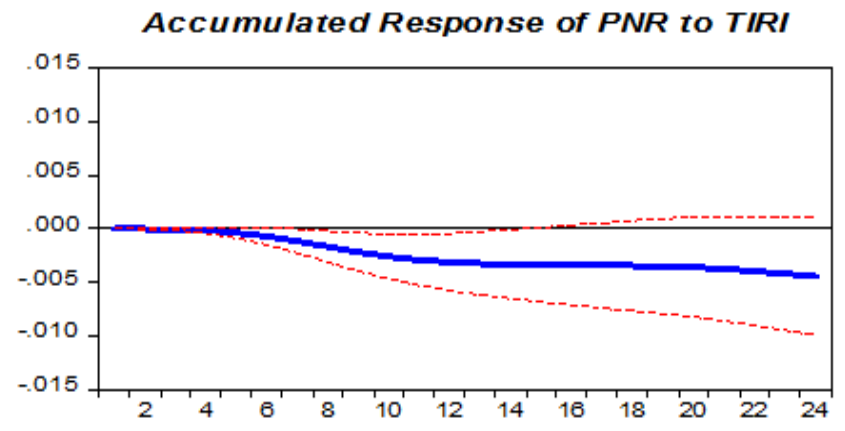

Accumulated Response of PNR to PNR

Accumulated Response of PNR to CC_PIB

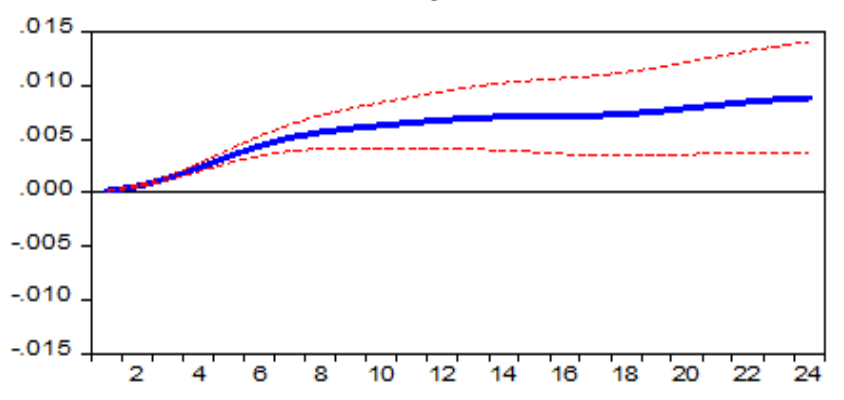

Accumulated Response of CC_PIB to TIRI
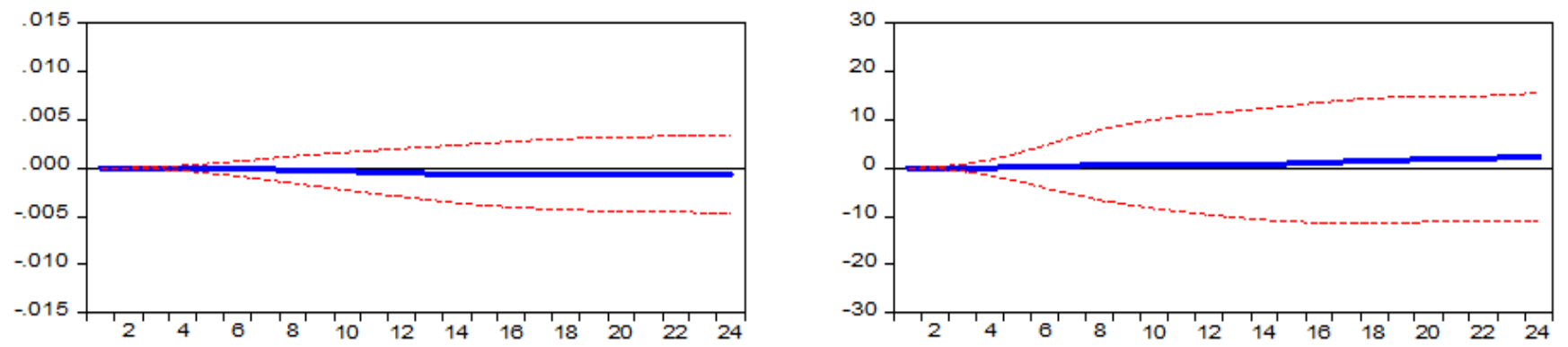

Accumulated Response of CC_PIB to PNR
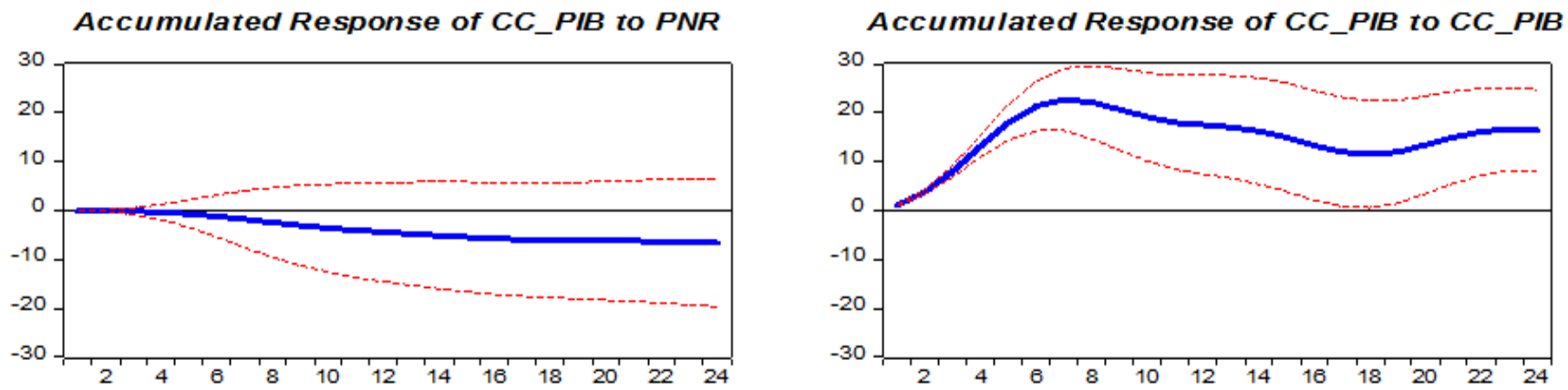

\section{SENEGAL}

Accumulated Response to Nonfactorized One S.D. Innovations \pm 2 S.E.

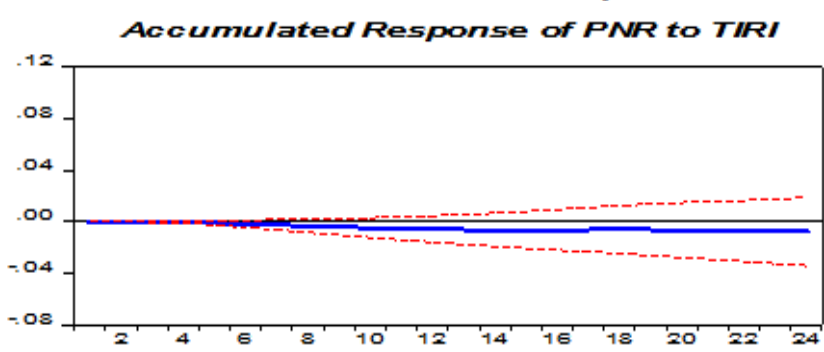

Accumulated Response of PNR to PNR

Accumulated Response of PNR to CC_PIB
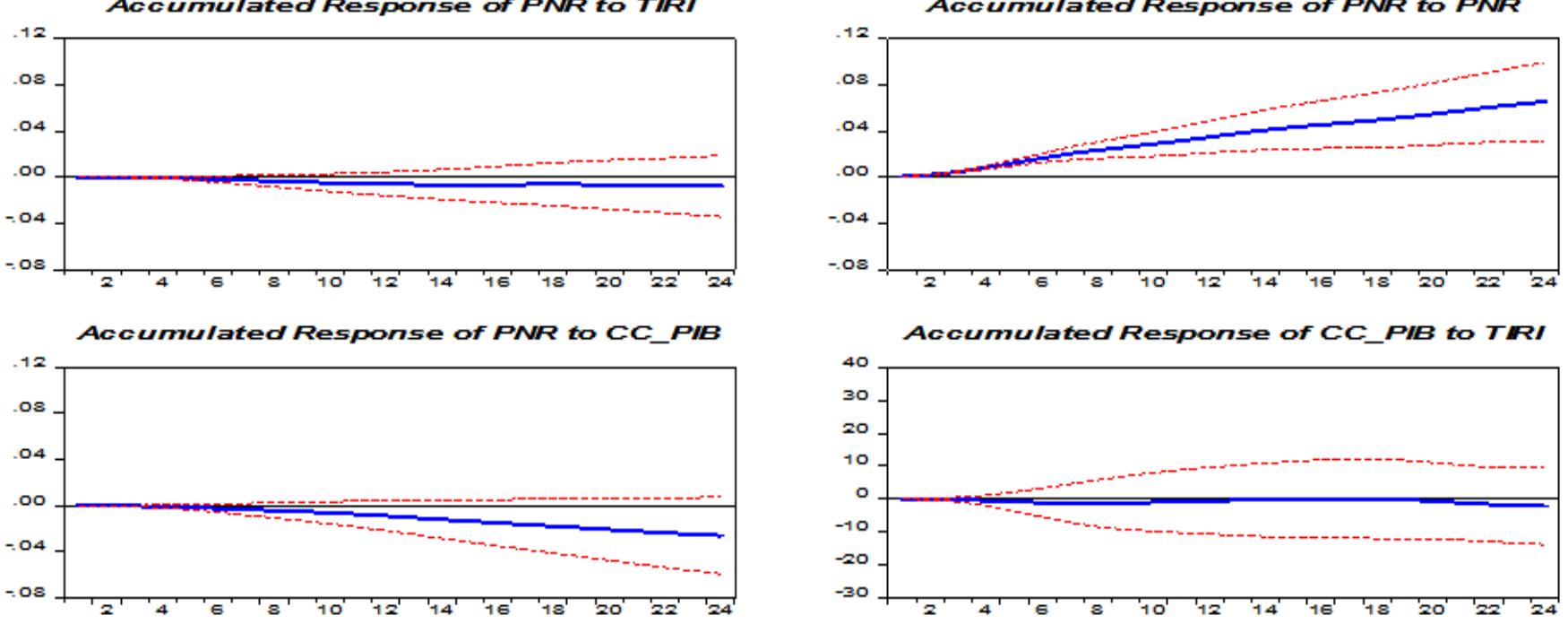

Accumulated Response of CC PIB to TR/
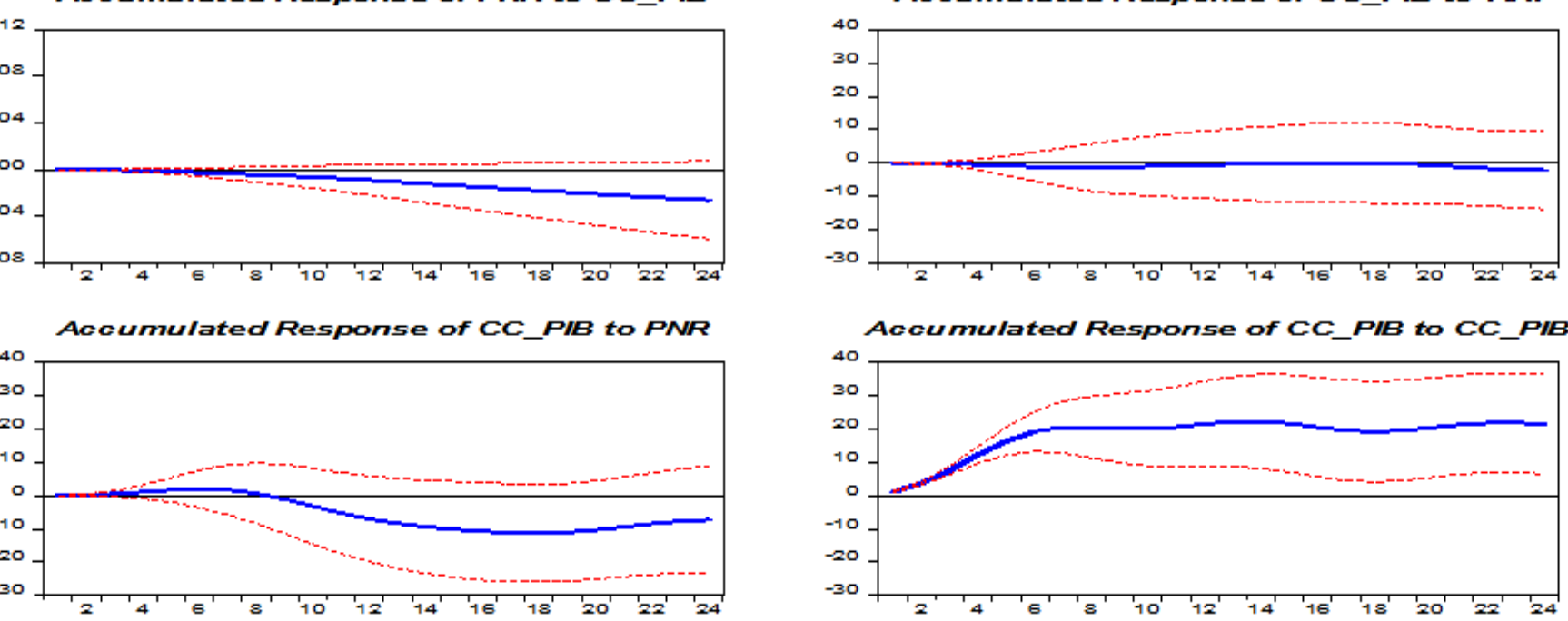


\section{TOGO}

Accumulated Response to Nonfactorized One S.D. Innovations \pm 2 S.E.

Accumulated Response of PNR to TIRI

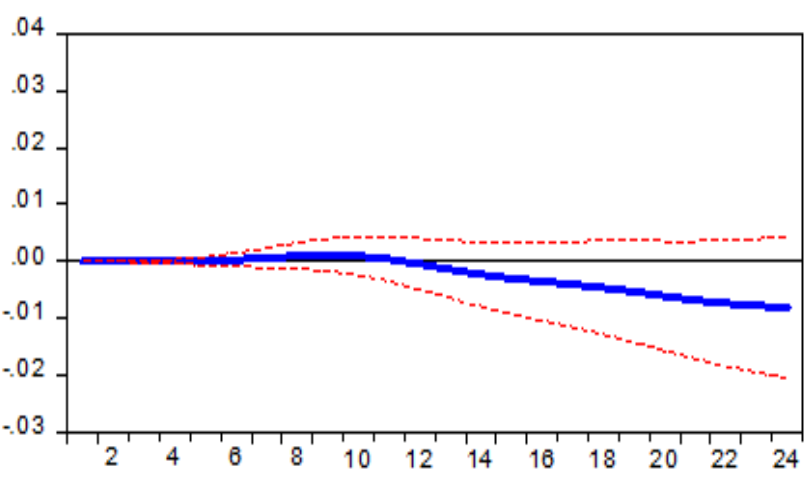

Accumulated Response of PNR to CC_PIB

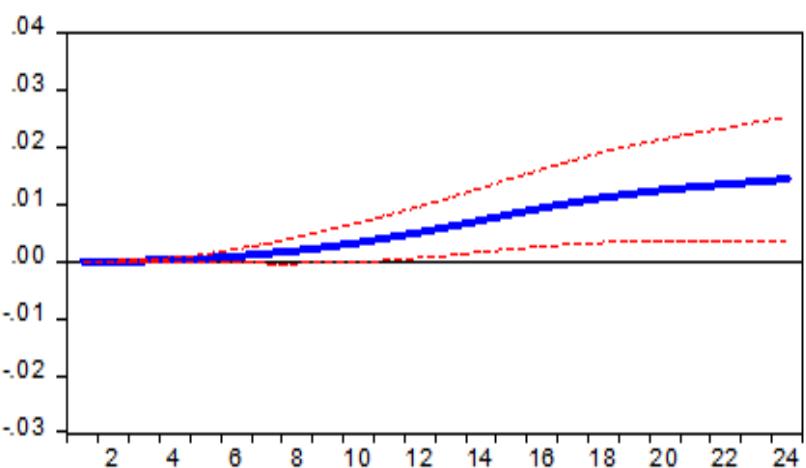

Accumulated Response of CC_PIB to PNR

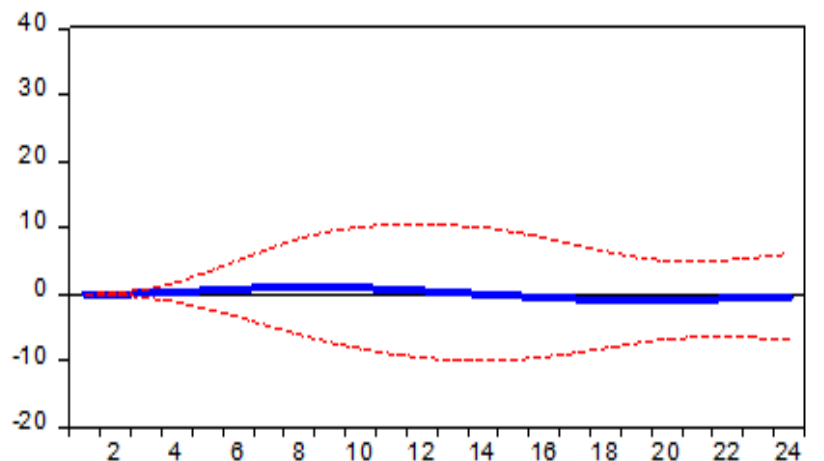

Accumulated Response of PNR to PNR

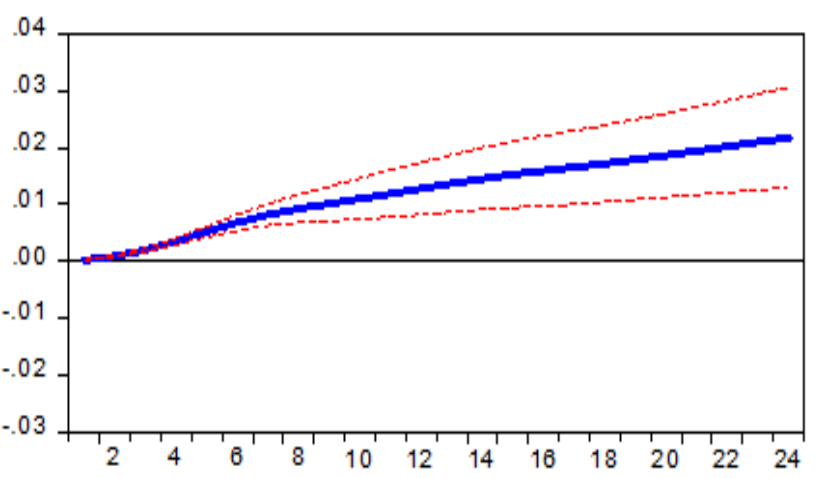

Accumulated Response of CC_PIB to TIRI

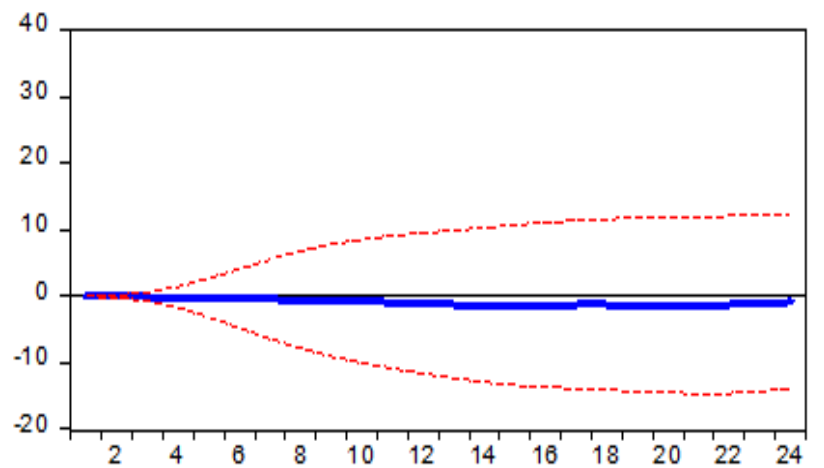

Accumulated Response of CC_PIB to CC_PIB

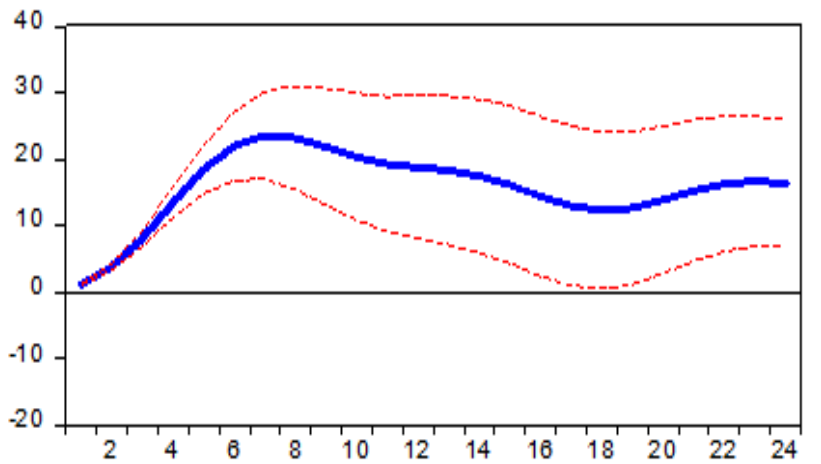

Figure-3. Impulse response functions.

Table-9. Decomposition of variance.

\begin{tabular}{|c|c|c|c|c|c|c|}
\hline \multicolumn{7}{|c|}{ 1. Benin } \\
\hline \multicolumn{7}{|c|}{ Variance Decomposition of NP } \\
\hline Period & \multicolumn{2}{|c|}{ S.E. } & \multicolumn{2}{|l|}{ Gs } & Ps & Ts \\
\hline 2 & \multicolumn{2}{|l|}{15.52636} & \multicolumn{2}{|l|}{46.04610} & 53.73720 & 0.216700 \\
\hline 10 & \multicolumn{2}{|l|}{51.05503} & \multicolumn{2}{|l|}{39.78096} & 59.98271 & 0.236329 \\
\hline 20 & \multicolumn{2}{|l|}{53.39300} & \multicolumn{2}{|l|}{49.55462} & 50.13471 & 0.310673 \\
\hline \multicolumn{7}{|c|}{ Variance Decomposition of CA/GDP } \\
\hline Period & \multicolumn{2}{|c|}{ S.E. } & \multicolumn{2}{|l|}{ Gs } & Ps & Ts \\
\hline 2 & \multicolumn{2}{|l|}{0.000654} & \multicolumn{2}{|l|}{2.089481} & 3.871050 & 94.03947 \\
\hline 10 & \multicolumn{2}{|l|}{0.003504} & \multicolumn{2}{|l|}{4.973667} & 7.616084 & 87.41025 \\
\hline 20 & \multicolumn{2}{|c|}{0.004136} & \multicolumn{2}{|l|}{4.846890} & 9.435648 & 85.71746 \\
\hline \multicolumn{7}{|c|}{ 2. Burkina Faso } \\
\hline \multicolumn{7}{|c|}{ Variance Decomposition of NP } \\
\hline Period & S.E. & Gs & \multicolumn{2}{|l|}{ Ps } & \multicolumn{2}{|l|}{ Ts } \\
\hline 2 & 0.000654 & 46.04610 & \multicolumn{2}{|l|}{53.73720} & \multicolumn{2}{|l|}{0.216700} \\
\hline 10 & 0.003504 & 39.78096 & \multicolumn{2}{|l|}{59.98271} & \multicolumn{2}{|l|}{0.236329} \\
\hline 20 & 0.004136 & 49.55462 & \multicolumn{2}{|l|}{50.13471} & \multicolumn{2}{|l|}{0.310673} \\
\hline \multicolumn{7}{|c|}{ Variance Decomposition of CA/GDP } \\
\hline \multicolumn{2}{|c|}{ Period } & S.E. & Gs & Ps & \multicolumn{2}{|l|}{ Ts } \\
\hline \multicolumn{2}{|l|}{2} & 2.864577 & 2.089481 & 3.871050 & \multicolumn{2}{|l|}{94.03947} \\
\hline \multicolumn{2}{|l|}{10} & 9.826025 & 4.973667 & 7.616084 & 87.41025 & \\
\hline 20 & & 10.43378 & 4.846890 & 9.435648 & 85.71746 & \\
\hline
\end{tabular}




\begin{tabular}{|c|c|c|c|c|}
\hline \multicolumn{5}{|c|}{ 3. Ivory Coast } \\
\hline \multicolumn{5}{|c|}{ Variance Decomposition of NP : } \\
\hline Period & S.E. & Gs & Ps & Ts \\
\hline 2 & 0.002815 & 22.11021 & 62.44739 & 15.44240 \\
\hline 10 & 0.018687 & 49.10754 & 44.64797 & 6.244490 \\
\hline 20 & 0.024034 & 53.47749 & 42.24102 & 4.281496 \\
\hline \multicolumn{5}{|c|}{ Variance Decomposition of CA/GDP: } \\
\hline Period & S.E. & Gs & Ps & Ts \\
\hline 2 & 2.800633 & 0.108973 & 0.646038 & 99.24499 \\
\hline 10 & 9.048979 & 0.750810 & 2.229074 & 97.02012 \\
\hline 20 & 10.17510 & 5.891720 & 10.75330 & 83.35498 \\
\hline
\end{tabular}

4. Mali

\begin{tabular}{l|l|l|l|l}
\hline \multicolumn{5}{l}{ Variance Decomposition of NP } \\
\hline Period & S.E. & Gs & Ps & Ts \\
\hline 2 & 0.001123 & 22.19861 & 77.03416 & 0.767231 \\
\hline 10 & 0.006174 & 12.67797 & 86.53404 & 0.787990 \\
\hline 20 & 0.008857 & 6.715274 & 92.43548 & 0.849245 \\
\hline Variance Decomposition of CA/GDP & Gs & Ps & Ts \\
\hline Period & S.E. & 24.96734 & 19.29179 & 55.74087 \\
\hline 2 & 2.721849 & 22.40393 & 27.00905 & 50.58702 \\
\hline 10 & 9.653075 & 21.83825 & 28.75692 & 49.40483 \\
\hline 20 & 10.35607 & &
\end{tabular}

\section{Niger}

Variance Decomposition of NP

\begin{tabular}{l|l|l|l|l}
\hline Period & S.E. & Gs & Ps & Ts \\
\hline 2 & 16.95850 & 13.94728 & 85.88413 & 0.168584 \\
\hline 10 & 52.80131 & 11.03605 & 88.84648 & 0.117468 \\
\hline 20 & 54.89289 & 11.46929 & 88.20483 & 0.325880 \\
\hline Variance Decomposition of CA/GDP & Gs & Ps & Ts \\
\hline Period & S.E. & Gs & 9.610384 & 97.04743 \\
\hline 2 & 0.000480 & 0.342190 & 5.132755 & 94.49982 \\
\hline 10 & 0.002258 & 0.367420 & 4.894546 & 94.54663 \\
\hline 20 & 0.002353 & 0.558828 & & \\
\hline
\end{tabular}

\section{Senegal}

Variance Decomposition of NP

\begin{tabular}{l|l|l|l|l}
\hline Period & S.E. & Gs & Ps & Ts \\
\hline 2 & 16.8147 & 31.2605 & 50.4522 & 18.2874 \\
\hline 10 & 52.7192 & 49.5352 & 40.3773 & 10.0876 \\
\hline 20 & 54.2568 & 47.6553 & 45.1056 & 7.23911 \\
\hline
\end{tabular}

Variance Decomposition of CA/GDP

\begin{tabular}{l|l|l|l|l}
\hline Period & S.E. & Gs & Ps & Ts \\
\hline 2 & 0.001537 & 2.525292 & 3.488888 & 93.98582 \\
\hline 10 & 0.008359 & 7.266887 & 7.293134 & 85.43998 \\
\hline 20 & 0.010518 & 10.53994 & 10.12012 & 79.33994 \\
\hline
\end{tabular}

7.Togo

Variance Decomposition of NP

\begin{tabular}{|c|c|c|c|c|}
\hline Period & S.E. & Gs & Ps & Ts \\
\hline 2 & 15.92043 & 1.070528 & 56.60889 & 42.32058 \\
\hline 10 & 52.01419 & 4.195602 & 74.40748 & 21.39691 \\
\hline 20 & 53.77925 & 20.25914 & 65.82229 & 13.91857 \\
\hline \multicolumn{5}{|c|}{ Variance Decomposition of CA/GDP } \\
\hline Period & S.E. & Gs & $\mathrm{Ps}$ & $\mathrm{Ts}$ \\
\hline 2 & 0.000689 & 1.561382 & 27.78531 & 70.65331 \\
\hline 10 & 0.003890 & 1.759554 & 30.48307 & 67.75738 \\
\hline 20 & 0.005449 & 1.751188 & 31.71975 & 66.52906 \\
\hline
\end{tabular}

Note: 1 Gs: Global shock.

Ps: Permanent shock.

Ts: Transitory shock. 